Research, part of a Special Feature on Programme on Ecosystem Change and Society (PECS): Knowledge for Sustainable Stewardship of Social-ecological Systems

\title{
Resilience to climate change in a cross-scale tourism governance context: a combined quantitative-qualitative network analysis
}

\author{
Tobias Luthe $^{1,2}$ and Romano Wyss ${ }^{3,4}$
}

\begin{abstract}
Social systems in mountain regions are exposed to a number of disturbances, such as climate change. Calls for conceptual and practical approaches on how to address climate change have been taken up in the literature. The resilience concept as a comprehensive theory-driven approach to address climate change has only recently increased in importance. Limited research has been undertaken concerning tourism and resilience from a network governance point of view. We analyze tourism supply chain networks with regard to resilience to climate change at the municipal governance scale of three Alpine villages. We compare these with a planned destination management organization (DMO) as a governance entity of the same three municipalities on the regional scale. Network measures are analyzed via a quantitative social network analysis (SNA) focusing on resilience from a tourism governance point of view. Results indicate higher resilience of the regional DMO because of a more flexible and diverse governance structure, more centralized steering of fast collective action, and improved innovative capacity, because of higher modularity and better core-periphery integration. Interpretations of quantitative results have been qualitatively validated by interviews and a workshop. We conclude that adaptation of tourism-dependent municipalities to gradual climate change should be dealt with at a regional governance scale and adaptation to sudden changes at a municipal scale. Overall, DMO building at a regional scale may enhance the resilience of tourism destinations, if the municipalities are well integrated.
\end{abstract}

Key Words: adaptation; climate change; core-periphery integration; social network analysis; stakeholder perceptions; tourism destination; transformation

\section{INTRODUCTION}

Alpine municipalities with tourism-dependent economies are exposed to a number of both short- and long-term disturbances, change processes, and challenges driven by climate change. In the Alps, the observed long-term climate trend confirms the over average projected rise of mean temperatures, resulting in diminishing snow covers, melting glaciers, and an increased risk of rock fall and landslides (Stocker et al. 2013). Related to Alpine tourism, there is evidence of two general types of climate-induced changes. First, sudden, fast changes, for example, the observed change in the frequency and intensity of daily temperature extremes, and second, slow, gradual changes, such as long-term trends of increasing mean temperatures (Stocker et al. 2013). Both types of change require either quick adaptation responses, or long-term strategies of mitigation and innovation. Mitigation in tourism reduces the emissions of greenhouse gases caused by the tourism sector to prevent further climate change (OECD 2007), innovation allows for a transformation of the tourism-based economy to become more diversified and less vulnerable to climate change. We focus on actions that require (social) innovation in the case of subjacent slow processes, including mitigation, and fast steering action in the case of imminent challenges (adaptation). Fast, sudden changes mostly relate to clearly identifiable adaptation tasks, whereas slow, gradual climate change mostly relates to more complex, not clearly identifiable actions of mitigation and innovation (Folke 2006). Both types of responses can either be coordinated by a governing body, for example, the local political council, a tourism destination management organization (DMO; e.g., Beritelli et al. 2007), or be implemented by individual actors or ad hoc groups of actors (see, e.g., Nordin and Svensson 2007). Therefore, climate change responses are to be understood as processes taking place at different scales of governance (see Ingold et al. 2010).

Calls for conceptual and practical approaches on how to address climate change have frequently been put forward in the literature (Faulkner 2001, Ahn et al. 2002, Ritchie 2004). The resilience concept, as a comprehensive theory-driven approach to address various forms of change, has only recently entered the scientific mainstream, especially with regard to tourism governance (Luthe and Wyss 2014). Resilience thinking allows an examination of various change factors through a single lens and provides insights into how the network of tourism actors, destinations, and regions can withstand and adapt to both long- and short-term changes (Luthe et al. 2012). Resilience of tourism municipalities and regions as local and regional social-ecological systems (SES) understood as networks of interrelated social, economic, and ecological components (see, e.g., Nelson et al. 2007) — describes the capacity of these systems to cope with external stresses, such as climate change (Holling 1973, Folke et al. 2005, Folke 2006). A tourism governance structure with the aim of supporting resilience has to meet two fundamental criteria, or governance modes (Folke et al. 2005, Manring 2007, Ernstson et al. 2010): (1) allow the preparation for disturbance via creating and maintaining the necessary level of diversity to plan for change while simultaneously enhancing decentralized processes of social learning and (2) allow the response to disturbance by the creation and maintenance of flexibility and by means of more centralized collective action. Flexibility allows for the implementation of short-term adaptation processes to imminent external challenges. In contrast to short-term shocks, long-term adaptation to more subtle changes implies learning processes and innovation, which call for the interaction of diverse actors throughout the system.

${ }^{1}$ University of Applied Sciences Chur, Institute for Tourism and Leisure, Switzerland, ${ }^{2}$ University of Freiburg, Centre for Key Qualifications, Germany, ${ }^{3}$ École Polytechnique Fédérale de Lausanne, Laboratory on Human-Environment Relations in Urban Systems, ${ }^{4}$ LMU University of Munich, Department of Geography 
A resilient SES is capable of switching between both governance modes for adapting to sudden changes and supporting social learning in the form of innovation, while experiencing different levels of stability. Thus, a resilient governance structure needs to enhance both, mode (1) translating to the aim of increasing innovative capacity, and mode (2) translating to the aim of building adaptive capacity.

The assessment of SES resilience from a network governance angle using quantitative and qualitative social network analysis (SNA) is a promising path of research (Luthe and Wyss 2014; I. Kelman, T. Luthe, R. Wyss, S. H. Tornblad, Y. Evers, M. M. Curran, and E. L. Berlow, unpublished manuscript). Only limited research has been published up to date on resilience of tourism destinations to climate-induced change; although there is a growing body of literature applying the resilience concept to tourism issues in general (Farrell and Twining-Ward 2004, Strickland-Munro et al. 2010, Ruiz-Ballesteros 2011, Becken 2013, Espiner and Becken 2014), only a few studies have been focusing specifically on the resilience of regional and local tourism systems to climate change. Most of these studies have been situated in marine and (sub)tropical environments (e.g., Lambert et al. 2010, Biggs 2011, Zeppel 2012), while there are only a handful of studies looking at resilience of Alpine SES from a network governance perspective (e.g., Luthe et al. 2012, Wyss et al. 2015).

Following this line of thought, the main objective of this paper is to test on what governance scale the Surselva-Gotthard tourism system is more resilient, on the municipal or on the regional scale. A related objective is to test and validate the interpretations of network metrics for assessing adaptive and innovative capacity derived from the literature with qualitative data and in-depth insights into perceptions and experiences from tourism stakeholders in this tourism system. To address these objectives, we analyze the adaptive and innovative capacity of the governance structure of the Swiss Surselva-Gotthard tourism SES at different scales of governance from a network point of view. We assess the collaborative social networks of tourism businesses and organizations of the region to analyze whether the resilience of the three municipalities Andermatt, Sedrun, and Disentis would be enhanced by the creation of the planned Gotthard destination management organization (DMO), a governance entity integrating the three municipalities on a regional scale. We validate the metric-based resilience interpretation of the tourism SES with perceptions of stakeholders from interviews and a workshop reflecting real social processes to allow for a more rigorous assessment and comparison of resilience.

\section{CLIMATE CHANGE IN THE SURSELVA-GOTTHARD REGION}

The economy of the Surselva-Gotthard region (Fig. 1) is strongly dependent on the tourism sector and especially on snow-based ski tourism in winter, while the economic development of the system is closely linked to the short-term variability and longterm trend of the regional and local climate. Many tourism offers and services in Alpine destinations, such as skiing, sledding or glacier-based activities, are highly vulnerable to climate change (Wyss et al. 2014). A direct link between the economic success of the municipalities in the Surselva-Gotthard region and meteorological conditions can be drawn. In the past decades, there has been a clear trend toward less snow in lower elevations and an overall higher variability and uncertainty in snow occurrence, leading to fewer ski tickets sales and overnight stays of visitors (Luthe et al. 2012). The snowline has risen by 48.9 meters per decade for the period 1960-2010, while the days with snow cover have been declining by approximately 10 days per decade (MeteoSwiss 2013). Based on the available data for Disentis, the winter seasons 2006/2007 and 2010/2011 were the driest and warmest on record (Beniston 2007, Uhlmann et al. 2009, Falk 2010), while in the winter of 2008/2009 the average accumulated snow coverage at an elevation of $1198 \mathrm{~m}$ above sea level was more than $90 \%$ above the average (MeteoSwiss 2013).

Fig. 1. Map of the Gotthard-Surselva region in Switzerland with the Oberalppass connecting Andermatt in the canton of Uri with Sedrun and Disentis in the canton of Grison (visualized with http://www.mappr.io based on Open Street Maps).

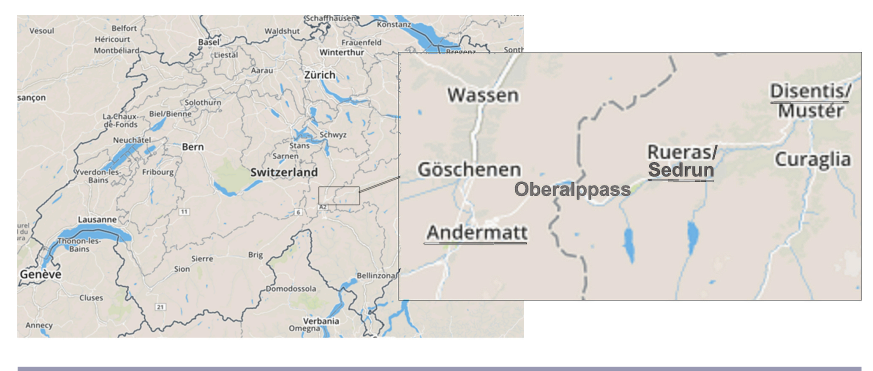

Additionally, there has been high variability in snow depths and temperatures in winter. For example, an extremely warm and dry season in 2006/2007 was followed by exceptionally snowy winters, such as the winter of 2008/2009 (see Luthe et al. 2012). In Disentis, both the number of overnight stays as well as the number of first entries of tourists into the ski area can be related to the variability in snow coverage, which itself depends on the variability of temperature and precipitation (see Luthe et al. 2012 for more details). Overall, the effects related to climate change such as warming temperatures and a lack of snow, together with other factors such as relatively low investments in tourism infrastructure, also have economic impacts, e.g., the fluctuations in overnight stays and first entries into ski areas (Luthe et al. 2012). Such effects have led to greater sensitivity of the tourism sector toward climate change and to competitive disadvantages for the region over the last decades in comparison to its direct competitors (BAK Basel 2006). In addition to coping with the impacts of climate change, the region is in a dynamic development state, with a major development project in Andermatt (Swiss Alpine Resort) creating new power relationships between SedrunDisentis (including the enclosed smaller municipalities of Sumvitg and Medel) on the southeastern and Andermatt on the northwestern slopes of the Oberalp pass (see http://www.bestandermatt.ch). The main current threat in the region is the strong link between the future development of the local tourism sector with the large-scale project in Andermatt, leading to new dependencies creating tension between and within actor groups. Alternative development patterns built upon regional strengths have been neglected (ClimAlpTour 2011, Siegrist et al. 2013). In this context, improved collaboration, integrated but centralized steering of action, and innovation to transform the economy 
based on winter tourism are of key importance to increase local and regional resilience.

\section{NETWORK GOVERNANCE AND RESILIENCE}

\section{Governance of tourism networks}

Governance can be defined as the "social and institutional structures and processes within which management processes take place" (Bodin and Crona 2009:366). In a tourism context, governance can be understood as the institutional setting, the frame of action within which individual entrepreneurs are active (Raich and Pechlaner 2006). For the study at hand, we understand the governance system as the network of actors grouped along the tourism supply chain and as a SES dependent on various regional resources and vulnerable to external pressure factors, such as climate change (Luthe et al. 2012, Wyss et al. 2014, 2015). Destinations with a tourism-dependent economy comprise a network of coproducing actors (Murphy et al. 2000, Flagestad and Hope 2001, Zehrer and Raich 2010) that are organized in the tourism supply chain. The tourism supply chain comprises seven economic sectors such as restaurants, hotels, and ski lifts, interacting with each other to provide localized tourism services (Michel 2001, Flagestad and Hope 2001).

Single destinations may collaborate with other destinations, developing a larger destination network governed by a collectively financed DMO. At the same time, they continue to maintain strong individual municipalities, leading to economic benefits but also to changes in local identity and culture (e.g., Oviero-Garcia et al. 2008, Pechlaner et al. 2012). Destination governance is dependent on the network of actors delivering a number of products and services (Ruhanen et al. 2010, Presenza and Cipollina, 2010, Haugland et al. 2011), while destination success, as well as that of individual actors, is dependent, among other aspects, on governing complex networks (Beritelli et al. 2007). Tourists experience their stay as one package, though such experiences comprise a multitude of services delivered by stakeholders along the tourism supply chain (Murphy et al. 2000, Michel 2001). The long-term success of individual business actors, as well as of the whole destination, depends on the collaboration, integration, and coordination of each actor's individual resources, activities, and services (Beritelli et al. 2007, Rodríguez-Diaz and Espino-Rodríguez 2008).

The need for collaboration and for understanding the tourism supply chain within a destination as a unit of enquiry has led to a rich body of literature on various aspects of collaborative destination development, for example, strategic planning (e.g., Formica and Kothari 2008), destination management (e.g., Sainaghi 2006), destination marketing (Wang and Xiang 2007), policy planning (e.g., Bramwell and Sharman 1999), and governance (e.g., Beritelli et al. 2007). The tourism literature acknowledges that better collaboration and coordination of activities can enhance the performance of both individual actors and destinations (e.g., Wang and Xiang 2007, Pansiri 2008). However, the development of such collaborative networks faces various challenges with respect to resources, common goals, and trust (Tinsley and Lynch 2001, Saxena and Ilbery 2008). However, cooperative behavior in tourism destinations is often found to be interpersonal and not primarily based on rational economic principles (e.g., Beritelli 2011).

\section{Adaptive and innovative capacity within and across governance scales}

On a local (municipal) governance scale, tourism destinations need to maintain closed intra-municipal ties to preserve social capital and to develop intermunicipal bridging ties with other destinations on a regional scale to gain new knowledge and possibilities of development and innovation (Beritelli et al. 2013a). Haugland et al. (2011) present a framework for such an integrated multiscale perspective on destination development. They argue that an analysis of the development and implementation of strategies, such as value creation, competitiveness, and economic growth, need to focus on multiple network scales and need to cross boundaries between different actors and actor groups. They propose that a destination's ability to develop such necessary multi- and cross-scale strategies will increase with the level of destination integration. They also highlight that the more ties exist between destinations (bridging ties), the more imitation and innovation (as forms of social learning) will potentially enhance the destination's individual ability to develop such multiscale strategies. Other authors have also pointed to the role of interorganizational cooperation and knowledge exchange within tourism systems (Svensson et al. 2005, Decelle 2006, Nordin and Svensson 2007). In this context, multiand cross-scale strategies allow the continued stability of a destination's economy while ensuring the flexibility needed for adaptation and the diversity required for social learning and innovation, referring to the two resilience aims of innovative and adaptive capacity. Innovation allows for the increase of what Walker et al. (2004) call the latitude of resilience by adapting to changing external conditions, in other words, it allows the system to preserve its current organizational state under changing external pressure factors. As part of a deliberate transformation process (Luthe and Wyss 2015), it also allows the system to reconfigure its structural properties under changing external factors (O’Brien 2012).

Many of the actors who take decisions and implement measures at a local governance scale are also embedded in other governance systems on multiple scales, which may be contextually related or not (Ingold et al. 2010, Hanssen et al. 2013). Social-ecological systems (SES) are more manageable on a lower scale, e.g., a patch of land is easier to manage than a whole landscape; but at the same time, the smaller system may be less resilient to change factors and external challenges (Gunderson and Holling 2002, Young 2002, Walker et al. 2004, Dakos et al. 2015). Within the same line of thought, Gunderson and Holling (2002) point to the fact that on a higher scale of organization, changes take place at a slower speed and over bigger areas. Changes on a higher scale can reciprocally influence adaptive processes on a lower scale, while changes on a lower scale can spark adaptive processes on a higher scale. Both are types of cross-scale governance. In tourism, destination-building processes on higher governance scales, often from municipal to regional scales, have been implemented for increasing cooperation and steering of collective action. The competitive advantage of tourism destinations increases with their size - the larger the boundaries of a DMO, the higher the competitive advantage toward other destinations (Beritelli et al. 2007), but the lower the destination effectiveness, especially with regard to internally organized tasks. There is an ongoing debate on resilient destination governance: in the future, successful 
tourism destination governance structures are expected to be less territorial and space based but more flexible and dynamic networks of various stakeholders (Beritelli et al. 2013b).

\section{Network structure and governance}

The analysis and interpretation of social networks is based upon the existence of structures on different network scales, differentiating the local (single node), meso (intermediate, groups of nodes), and global (whole network level) scales (Rombach et al. 2014). The meso-scale network structure, such as a community structure or a core-periphery structure, deserves special attention since it allows for insights into network features that are not apparent on the local or global network scale (Rombach et al. 2014). Communities, in a network science understanding (not to be mistaken with communities or municipalities in a governance understanding) are subgroups or clusters with a larger density of ties between nodes than to any nodes belonging to a different subnetwork (Boccaletti et al. 2006). The existence of subgroups is a sign of local inhomogeneity, which may hinder overall collaboration because of the existence of strong bonding ties within the subgroups, but may support the creation of new ideas and thus support innovation (Crona and Bodin 2006, Bodin and Crona 2009).

Core-periphery structures exist when a small number of central actors or hubs hold a disproportionate amount of connections, while most other nodes maintain few relationships (Girvan and Newman 2002, Guimerà et al. 2003, Newman and Girvan 2004, Guimerà and Amaral 2005a, Hojman and Szeidl 2008, Rombach et al. 2014). A substantial variety of connections within the core as well as from the core to more peripheral actors (resulting in a broker/gatekeeper position of some of the central actors) have been shown to be ideal for the overall innovative capacity of a social network in a regional governance context (Ter Wal and Boschma 2009, Kauffeld-Monz and Fritsch 2013). The role of core-periphery integration has therefore been discussed with respect to regional innovation systems (Asheim and Isakson 1997), innovation in creative industries (Cattani and Ferriani 2008), and innovation diffusion (Valente 1995, Abrahamson and Rosenkopf 1997). The inflow of information from actors in the periphery of a network toward more central actors leads to challenging predominant ideas and practices by core actors and can potentially prevent lock-in effects (Allison and Hobbs 2004, Martin and Sunley 2006, Hassink 2010).

In the context of resilience, the existence of very central coreactors is important because these support the adoption and implementation of new ideas from the periphery because coreactors are often connected to central nodes in other networks, bridge the two networks, and thus grant access to potential decision makers (Bodin and Crona 2009). A system with a high degree of diversity of actors and ties allows for the integration of information between subgroups as well as between the core and the periphery of the system, while allowing the actors to acquire ideas from the outside (see Luthe et al. 2012 for a more extensive discussion). Despite its wide use, the core-periphery concept still lacks a formal definition for the separation of the core from the periphery, though a number of intuitive understandings have been mentioned in the literature (e.g., Breiger 1981, Wasserman and Faust 1994, Scott 2013, Rombach et al. 2014) and reviewed by Borgatti and Everett (2000). Empirically supported examples of the core-periphery concept include networks of disease dynamics
(Kitchovitch and Liò 2011), spatial group interaction (Onnela et al. 2011), scientific collaboration and citations (Mullins et al. 1977, Newman 2004), friendship (Adaic and Adar 2003), advice in the workplace (Cross et al. 2001), and interlocking directorates of corporations (Mizruchi 1996).

\section{A governance structure supporting resilience}

The introduced two governance modes describing a resilient (tourism) SES, (1) innovative and (2) adaptive capacity, are related to structural properties of the social network of coproducing actors of the tourism supply chain. These can be found in a multiscale integration of actors on the local (within communities) and regional (in between municipalities) governance scale, in a meso-scale network structure with existing clusters and a coreperiphery structure, and in a multiscale integration between entities on different governance scales, such as a municipality and a region comprising multiple municipalities. Resilience of tourism SES to long-term, e.g., gradually rising average snow line, development is dependent on social learning and diversity to prepare for change; resilience to short-term, e.g., dry winter, developments is dependent on adaptation by central steering of collaborative action between stakeholders of the tourism supply chain and those from the public sector. A governance structure supporting resilience would, revisiting the above discussed two governance aims, be able to (1) prepare for gradual changes by fostering social learning and innovation, and (2) react to shortterm shocks demanding quick distribution of information and centralized steering of collective action (adaptation), while dynamically switching between both modes. Examples for aim (1) are the diversification of the regional economy and the reduction of snow dependency by creating new snow-independent products, for aim (2) the technical production of snow. Based on this understanding of the role of structural network properties for resilient governance of a (tourism) SES, the social network analysis (SNA) literature provides metrics to assess and measure the innovative and adaptive capacity of such systems.

\section{MATERIAL AND METHODS}

Network metrics and their interpretation for assessing resilience The broad literature on network governance proposes a number of network metrics to assess resilience of social (-ecological) systems based on connectivity and structural network properties on local, intermediate (meso-), and global scales. Among the most commonly used global summary statistics are network size, density, average degree centrality, and global efficiency; often used local statistics are degree-, betweenness-, and closeness centrality, and local efficiency; a meso-scale structure can be expressed through modularity and cohesion (clustering; e.g., Burt 2004 Costa et al. 2007, Olsson et al. 2007, Scott et al. 2008a, Bodin and Crona 2009, Baggio et al. 2010a,b, Baggio 2011). The interpretation of these metrics for resilience of SES and their meanings for adaptive and innovative capacities are summarized in Table 1.

Network metrics supporting aim (1), innovative capacity, are a larger size of the network if diversities of ties and nodes increase (Walker et al. 2004), a lower centralization, centrality, and average degree to prevent lock-in effects and to support decentralized exchange and peripheral infusion of information (Bodin et al. 2006, Sandström and Carlsson 2008, Costa and Baggio 2009), a higher modularity with an existing community structure 
Table 1. Network metrics analyzed in this paper and their interpretation of resilience in social networks based on the literature.

\begin{tabular}{|c|c|c|}
\hline Network metric & Description & $\begin{array}{l}\text { Indication of innovative (aim 1) and adaptive capacity (aim 2) } \\
\text { of a resilient governance structure }\end{array}$ \\
\hline Size & $\begin{array}{l}\text { Total number of nodes (actors) and ties (connections) in a } \\
\text { network. }\end{array}$ & $\begin{array}{l}\text { Larger systems tend to be more efficient in resource use and } \\
\text { find more comprehensive approaches to equity, thus they may } \\
\text { be more resilient to change factors and external challenges. } \\
\text { Smaller systems may be easier to manage and faster to cope } \\
\text { with local variations and specifications (Gunderson and } \\
\text { Holling 2002, Young 2002, Walker et al. 2004, Dakos et al. } \\
\text { 2015). }\end{array}$ \\
\hline Density & $\begin{array}{l}\text { Ratio between the existing number of ties and the maximum } \\
\text { possible number of ties in a graph. }\end{array}$ & $\begin{array}{l}\text { The denser the network the better the chances for } \\
\text { collaboration (Olsson et al. 2004). The density of a network } \\
\text { can have contradictory effects upon the innovation capacity: a } \\
\text { high density increases trust (Bodin et al. 2006), but can lead to } \\
\text { homogenization of ideas and perceptions (Oh et al. 2004). }\end{array}$ \\
\hline Centrality & Importance of single nodes (or ties) in a network. & $\begin{array}{l}\text { High centrality supports solving simple tasks and } \\
\text { coordination, but may hinder social learning because access of } \\
\text { individual actors to information is limited (Bodin et al. 2006). }\end{array}$ \\
\hline Degree centrality & $\begin{array}{l}\text { Importance of single nodes in a network based on the } \\
\text { number of ties a node has. }\end{array}$ & $\begin{array}{l}\text { High degree centrality supports actors in making their } \\
\text { concerns heard and actively steer governance processes but } \\
\text { may also lead to constrained possibilities for action because of } \\
\text { too many obligations to please (Bodin and Crona 2009). }\end{array}$ \\
\hline Betweenness centrality & $\begin{array}{l}\text { Describes the central function an actor has in connecting } \\
\text { others. }\end{array}$ & $\begin{array}{l}\text { Actors with high betweenness centrality often serve as } \\
\text { gatekeepers or brokers who connect across scales and levels, of } \\
\text { importance for connecting subgroups and insuring the flow of } \\
\text { information, and for assuring knowledge circulation for } \\
\text { innovation and for the distribution of information toward and } \\
\text { from the periphery (core-periphery integration; Bodin and } \\
\text { Crona 2009). }\end{array}$ \\
\hline Closeness centrality & Measures how close actors are to others in a network. & $\begin{array}{l}\text { Actors with high closeness centrality can better react to } \\
\text { sudden changes since they can quickly take over coordination } \\
\text { tasks (Scott et al. } 2008 a \text { ). }\end{array}$ \\
\hline Average degree & $\begin{array}{l}\text { Describes the arithmetical mean of all node degree } \\
\text { centralities, a measure for the centralization of the network. }\end{array}$ & $\begin{array}{l}\text { A high average degree describes a more centralized network, } \\
\text { allowing for centralized steering of (fast) collective action, but } \\
\text { hindering adaptation to complex tasks and potentially leading } \\
\text { to lock-in effects (Sandström and Carlsson 2008). High } \\
\text { centralization may leed to lock-in effects and supress } \\
\text { innovation entering from the periphery, but it may also } \\
\text { support innovation by the connections of highly central actors } \\
\text { with decision makers from other networks (Costa and Baggio } \\
\text { 2009). }\end{array}$ \\
\hline Modularity index Q & $\begin{array}{l}\text { Measure for the tendency to form modular subgroups or } \\
\text { communities in a graph, where a group of nodes has more } \\
\text { dense ties within than to nodes outside the group. Q is the } \\
\text { fraction of all edges that lie within a community minus the } \\
\text { expected value of the same quantity in a graph in which the } \\
\text { nodes have the same degrees but edges are placed at random. }\end{array}$ & $\begin{array}{l}\text { High modularity indicates the existence of subgroups, which } \\
\text { may hinder overall collaboration because of the existence of } \\
\text { strong bonding ties within the subgroups, but may support the } \\
\text { creation of new ideas and thus support innovation (Bodin and } \\
\text { Crona 2009, Crona and Bodin 2006). Negative modularity } \\
\text { indicates the tendency to connect outside the subgroup } \\
\text { (Baggio 2011). }\end{array}$ \\
\hline Clustering coefficient & $\begin{array}{l}\text { The ratio between the number of ties connecting the } \\
\text { neighborhood and the total possible number of ties in that } \\
\text { neighborhood: a measure of local inhomogeneity of the tie } \\
\text { density. }\end{array}$ & $\begin{array}{l}\text { High cohesion (indicated by a high clustering coefficient) as a } \\
\text { measure of local inhomogeneity may increase the amount } \\
\text { (and possibly speed) of information flow and thus inclusion of } \\
\text { actors for collective action especially regarding sudden } \\
\text { changes (Bodin and Crona } 2009 \text {, Baggio et al. } 2010 \mathrm{~b} \text { ). }\end{array}$ \\
\hline Average path length & $\begin{array}{l}\text { The arithmetical mean of all tie distances (shortest direct } \\
\text { connections) between any two nodes in the network. }\end{array}$ & $\begin{array}{l}\text { The shorter the average path length, the faster information in } \\
\text { a network can flow, of importance for reacting to sudden } \\
\text { changes (Scott et al. 2008b). }\end{array}$ \\
\hline Efficiency & $\begin{array}{l}\text { Efficiencies are the arithmetical means of inverse tie distances } \\
\text { on a global (network) and a local (node) level. }\end{array}$ & $\begin{array}{l}\text { Global efficiency measures the capability of a network to } \\
\text { exchange information. Local efficiency measures the } \\
\text { capability of a single node to exchange information (Baggio et } \\
\text { al. } 2010 b \text { ). }\end{array}$ \\
\hline
\end{tabular}

supporting the creation of new ideas (Bodin and Crona 2009), and a higher global efficiency (Table 1). Metrics supporting aim (2), adaptive capacity, in comparison, are a smaller size of the network because smaller networks are easier to manage (Walker et al. 2004), a higher centralization, average degree, and centrality because both support coordination and the solving of simple tasks (Bodin et al. 2006), a lower modularity that enhances collaboration (Bodin and Crona 2009), a higher cohesion (indicated by a high clustering coefficient) that may enhance amount and speed of information flow for fast collective action (Baggio et al. 2010b), a shorter average path length and higher 
Fig. 2. The destination management organization (DMO) network both in a force-directed layout (left side, displaying the centralized structure of the DMO) and in a clustering layout (right side), sized by actors of the core (bigger nodes) and of the periphery (smaller nodes), and labeled by the tourism supply chain sectors (http://www.mappr.io). Colors indicate the validation of the metrics interpretation.
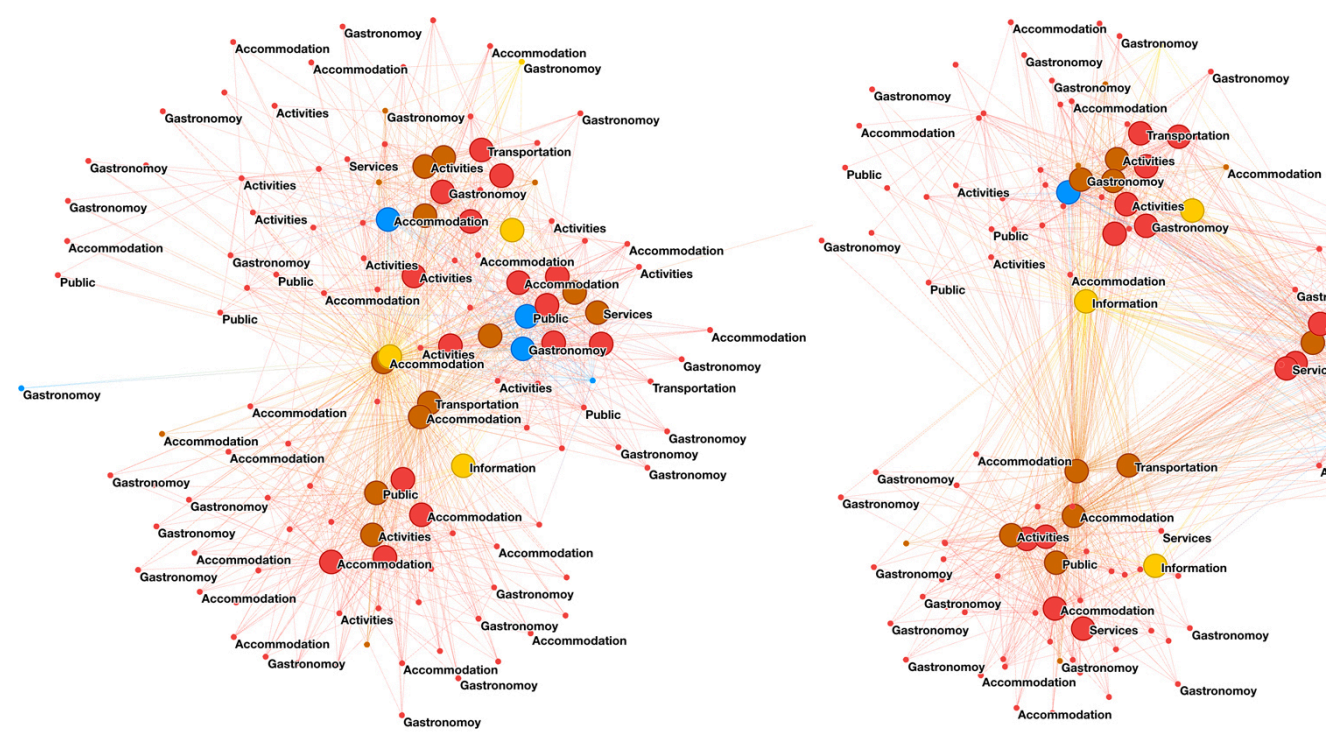

local efficiency, both enhancing the speed in exchange of information (Scott et al. 2008b, Baggio et al. 2010b; see Table 1).

Ideally, a resilient governance structure has a well-integrated coreperiphery structure and an existing multiscale integration, i.e., between the municipal and the regional governance scales. Connectivity as the structure and strength of information or resource flows in networks is highly context dependent though (Dakos et al. 2015). In general, intermediate levels of connectivity are often considered better than the extremes of very high or very low levels (Salau et al. 2012, Schoon et al. 2014, Dakos et al. 2015).

Though theoretically established in the literature, the resilience interpretations of the presented metrics are generally drawn from empirically derived assumptions. To date there is little empirical evidence for the validation of such interpretations, for example by qualitative data analysis and an in-depth understanding of the existing, underlying social processes, or by longitudinal studies (Luthe and Wyss 2014). In this paper, we base our assessment of resilience of the Surselva-Gotthard tourism system on such interpretations of network metrics, but validate these quantitative results in relation to an in-depth understanding of the underlying social processes in the region derived from qualitative interviews and workshop data.

\section{Building upon published quantitative SNA data}

To address our objectives, we applied a combination of quantitative SNA and qualitative interviews. We based our comparative analysis on published data from the European Interreg Alpine Space cross-border project ClimAlpTour Climate Change and its Impact on Tourism in the Alpine Space (ClimAlpTour 2011, Clivaz et al. 2012). In ClimAlpTour an SNA of the same three municipalities was conducted that allowed for a resilience assessment based on network topologies (described in Luthe et al. 2012). These data were gathered by sending out a standardized written questionnaire to all identified stakeholders from the tourism supply chain, including public authorities from the municipalities, the region, and the cantons of Grisons and Uri, and NGOs, such as the Swiss Alpine Club and its regional mountain huts $(\mathrm{n}=170$, participation rate $42 \%)$. These stakeholders were owners, managers, or official representatives of the tourism businesses from the supply chain and from the named authorities and organizations. We refer to them either as stakeholders or actors. In the questionnaire, the 170 actors were asked to indicate with whom they have a business collaboration, and what the quality, scope, and success of such collaborative ties are. This final network comprised 159 actors (11 actors had no connections and were deleted) and 1814 undirected ties. A tie in this network is a named collaboration between stakeholders of the tourism supply chain. No further information on the quality of the tie is included in this analysis.

\section{The quantitative SNA sample of this paper}

For the quantitative analysis, we excluded those 26 stakeholders from the public sector and other actors and their ties that were not based in one of the three municipalities of Andermatt, Sedrun, and Disentis from the original network published in Luthe et al. (2012). This new and smaller regional network $(\mathrm{n}=$ 133 actors with 1420 ties, Fig. 2) was congruent with the planned Gotthard DMO and allowed for comparison with the networks of the three individual, independently analyzed municipalities, without the influences of actors outside the region. We first recalculated the metrics (Table 2) of this new, smaller (regional) DMO network and its three independent municipal networks (by deleting the intermunicipal ties). We then analyzed and compared both governance entities - the individual municipalities and the planned regional DMO - regarding their resilience to climate change by presenting network topology results for the four networks based on the metrics for interpreting resilience (Table 
Table 2. Metrics of the analyzed networks. DMO indicates destination management organization.

\begin{tabular}{|c|c|c|c|c|}
\hline & Gotthard DMO & Andermatt & Sedrun & Disentis \\
\hline \multicolumn{5}{|l|}{ Nodes/links } \\
\hline full network & $133 / 1420$ & $52 / 259$ & $50 / 448$ & $31 / 176$ \\
\hline core & $33 / 436$ & $9 / 50$ & $16 / 185$ & $8 / 46$ \\
\hline periphery & $100 / 143$ & $43 / 35$ & $34 / 43$ & $23 / 33$ \\
\hline \multicolumn{5}{|l|}{ Density \% } \\
\hline full network & 7.3 & 9.8 & 18.3 & 18.9 \\
\hline core & 36.6 & 69.4 & 77.1 & 82.1 \\
\hline periphery & 1.3 & 1.9 & 3.8 & 6.5 \\
\hline Modularity full network & 0.337 & 0.138 & 0.173 & 0.116 \\
\hline randomized version & 0.168 & 0.22 & 0.137 & 0.145 \\
\hline $\begin{array}{l}\text { Modularity core-periphery } \\
\text { division }\end{array}$ & -0.007 & -0.039 & 0.031 & 0.017 \\
\hline Clustering & 0.453 & 0.571 & 0.51 & 0.485 \\
\hline Average degree & 10.14 & 4.98 & 8.96 & 5.67 \\
\hline Average path length & 2.12 & 1.84 & 1.69 & 1.77 \\
\hline Global efficiency & 0.21 & 0.198 & 0.294 & 0.339 \\
\hline Local efficiency & 0.649 & 0.747 & 0.66 & 0.647 \\
\hline
\end{tabular}

1). We tested on which scale the two aims of innovative and adaptive capacity were better met. The software Visone (Brandes and Wagner 2004, http://www.visone.info) was used for the analysis (apart from the modularity analysis and core-periphery detection, see below), the software mappr (http://www.mappr.io) for the visualization of the networks.

\section{Detection and analysis of a meso-scale network structure}

\section{Detection of a community structure}

As part of the network analysis we performed a modularity analysis to detect a possible community structure in the networks and, based on this, interpreted the innovative capacities of the municipalities and the regional DMO based on the literature (Table 1). The literature offers different approaches to detect a community structure (e.g., Guimerà et al. 2003, Guimerà and Amaral 2005a,b, Kitchovitch and Liò 2011). We used the method proposed by Blondel et al. (2008) with the widely applied Louvain0 modularity detection implemented in Gephi (Bastian 2009, http://gephi.github.io) to algorithmically identify a possible subgroup structure of the networks (reported as full network in Table 2). As a comparison, the values calculated for networks of the same sizes and average degrees as the initial networks but with random distributions of ties are provided.

\section{Analysis of core-periphery integration}

We tested the existence of a core-periphery structure and compared the integration of the network cores with their peripheries on the municipal scale with the regional DMO governance scale. The networks were divided into a more densely connected, more central core and a sparsely connected periphery, using the algorithm presented by Borgatti and Everett (2000) and implemented in Ucinet (Borgatti et al. 2002). The sizes of the cores and the peripheries are shown in Table 2. The modularity index (Newman and Girvan 2004) of this division was calculated following the process described in Baggio (2011) and in Costa and Baggio (2009) to test whether nodes in the cores and the peripheries tended to connect within or outside the core/ periphery. Negative modularity describes the tendency of nodes to connect with nodes outside their own group, thus indicating higher core-periphery integration (Baggio 2011).

Qualitative data to validate the interpretation of network metrics We validated the interpretations of the network metrics with qualitative data from a workshop and from personal interviews to obtain an in-depth understanding of the social processes and perceptions. In this accompanying qualitative study, 20 actors from the same SNA sample were interviewed to (I) test the validity of their responses to the quantitative SNA questionnaires (Luthe et al. 2012), to (II) evaluate their perceptions related to social processes and their revealed network positions, and (III) to validate the interpretation of the resilience metrics from the quantitative part of this study. The 20 actors were selected from the SNA sample to include a high diversity of actors (i) from each of the three municipalities, (ii) covering the seven supply chain sectors, and (iii) including actors of high, medium, and low betweenness centrality. Peripheral and more isolated actors were specifically included to display perceptions of such actors as well. This network position-based selection ensured the inclusion of actors representing the municipalities and the region from a functional network perspective (Table 3, Fig. 2).

The 20 personal interviews lasted between 45 to 90 minutes. All 20 persons contacted agreed to participate in the interviews. The semistructured interview protocol was pretested with tourism experts. The protocol included questions about the validation of the quantitative questionnaires, the quality of cooperation, the perceived focus and relevance of collaboration, the perceptions of their network positions and functions in the municipality and the region, and whether their level of cooperation was expected to increase in the future (Table 4). Other questions addressed the general situation of collaboration in the region and the plans and actions for individual climate change adaptation. At the end of the interviews, the interviewer showed the network graph of the region to actors to test their reactions regarding their overall position in the network, based on the quantitative SNA. The responses were audio-recorded, transcribed, coded, and 
Table 3. Centrality measures of the 20 interviewees.

\begin{tabular}{|c|c|c|c|c|c|c|}
\hline & Actor & Supply chain sector & Community & $\begin{array}{c}\text { Betweenness } \\
\text { centrality }\end{array}$ & Degree centrality & $\begin{array}{l}\text { Closeness } \\
\text { centrality }\end{array}$ \\
\hline 1 & Municipality 1 & Public Sector & Sedrun & 17.85 & 5.28 & 0.89 \\
\hline 2 & Hotel 1 & Accommodation & Sedrun & 11.93 & 4.37 & 0.92 \\
\hline 3 & Hotel 2 & Accommodation & Sedrun & 11.08 & 5.14 & 0.81 \\
\hline 4 & Cableways 1 & Transportation & Sedrun & 9.54 & 2.43 & 1.1 \\
\hline 5 & Municipality 2 & Public Sector & Andermatt & 5.54 & 2.43 & 0.84 \\
\hline 6 & Cableways 2 & Transportation & Disentis & 5.29 & 1.87 & 0.99 \\
\hline 7 & Tourism Information 1 & Information & Andermatt & 5.09 & 0.99 & 0.91 \\
\hline 8 & Railway company & Transportation & Andermatt & 3.2 & 1.3 & 0.87 \\
\hline 9 & Skischool 1 & Activities & Andermatt & 2.64 & 1.9 & 0.82 \\
\hline 10 & Golfclub & Activities & Sedrun & 2.33 & 1.51 & 0.86 \\
\hline 11 & Restaurant 1 & Gastronomy & Disentis & 2.02 & 1.54 & 0.79 \\
\hline 12 & Bed \& Breakfast & Accommodation & Disentis & 1.94 & 1.26 & 0.72 \\
\hline 13 & Skischool 2 & Activities & Disentis & 1.85 & 1.44 & 0.84 \\
\hline 14 & Cafe 1 & Gastronomy & Disentis & 0.67 & 0.49 & 0.65 \\
\hline 15 & Restaurant 2 & Gastronomy & Andermatt & 0.4 & 0.59 & 0.81 \\
\hline 16 & Cableways 3 & Transportation & Andermatt & 0 & 0.94 & 1.08 \\
\hline 17 & Bar 1 & Entertainment & Disentis & 0 & 0.35 & 0.83 \\
\hline 18 & Bar 2 & Entertainment & Andermatt & 0 & 0.31 & 0.72 \\
\hline 19 & Tourism Information 2 & Information & Sedrun & 0 & 1.16 & 0 \\
\hline 20 & Municipality 3 & Public Sector & Disentis & 0 & 0.59 & 0.83 \\
\hline
\end{tabular}

aggregated in the categories of the semistructured questionnaire guidelines shown in Table 4, using qualitative content analysis methods (Brosius and Koschel 2001, Mayring 2000).

\section{NETWORK METRICS AND THEIR INTERPRETATION}

We present the network metrics and their interpretation for resilience of the municipal networks compared to the regional DMO network, according to the metrics listed in Table 1.

\section{Size and density}

Andermatt is, with 52 nodes, the largest municipal network, followed by Sedrun (50) and Disentis (31; Fig. 2). The regional DMO has a lower density than the municipalities, signaling a lower potential for collaboration and information exchange on the regional governance scale (see Table 2). The lower density may support innovative capacity by not leading to homogenization of ideas and perceptions (Table 1).

\section{Centrality and centralization}

All networks were scale-free and exhibit a power-law distribution in terms of degree centrality. At 10.143, the regional DMO average degree was higher than in the municipalities of Andermatt (4.981 $49 \%$ of DMO), Disentis (5.677 - 56\% of DMO), and Sedrun (8.96 $78 \%$ of DMO), indicating a higher potential for steering collective action in the DMO and for adopting and implementing ideas through access to other networks (Table 2).

The DMO actors had a high range of centrality degrees (spread from low to high centrality; Table 3), supporting diversity and thus innovative capacity of the network, which was similar on the municipal scale (see the regional, including the 19 actors from outside the region, and the municipal degrees in Luthe et al. 2012). In the regional DMO, the four most betweenness central actors were from Sedrun from three different supply chain sectors, which underlined the brokerage (and thus integrative) function that Sedrun takes between Andermatt and Disentis (as entities of actors). In degree centrality, we found a similar situation where actors from Sedrun were best positioned in the DMO to steer governance processes. The situation was different when analyzing closeness centrality. The cableway actors from each municipality were most central in the DMO and were best equipped to quickly take over coordination tasks to react to sudden changes (Table 3). Cableways were the main economic drivers of many wintertourism-oriented Alpine municipalities and took over an important position in the tourism supply chain. In Andermatt, Disentis and Sedrun, the distributions of centrality degrees by sector were quite similar, except that the cableways in Disentis were most central with regard to all three centrality measures.

\section{Modularity and community structure}

The regional DMO modularity with 0.337 was approximately 2-3 times higher than modularities on the municipal governance scale (Table 2). In comparison with randomized networks, the DMO modularity difference was the highest, indicating a higher tendency to form subgroups and a higher potential for diversity of ideas. The DMO had a modular community structure that displayed the municipal and geographical borders of the three municipalities (Figs. 2 and 3; I. Kelman, T. Luthe, R. Wyss, S. H. Tornblad, Y. Evers, M. M. Curran, and E. L. Berlow, unpublished manuscript). The DMO was potentially better in supporting social learning and incubating innovation than the municipalities, supporting aim (1) of a resilient tourism SES governance structure.

\section{Core-periphery structure and modularity}

The networks showed a clear core-periphery structure. The sizes of the cores and the peripheries are shown in Table 2 . The regional DMO core $(36.6 \%)$ and periphery densities $(1.3 \%)$ were the lowest compared to the municipalities. The densities of the cores and the peripheries in the individual municipalities were lowest in Andermatt, followed by Sedrun and Disentis. Following the 
Table 4. Aggregated results from the 20 interviews. (x) indicates a confirmation, (-) a denial, and an empty cell indicates that the topic was not mentioned. SNA indicates social network analysis; DMO indicates destination management organization.

\begin{tabular}{|c|c|c|c|c|c|c|c|c|c|c|c|c|c|c|c|c|c|c|c|c|c|}
\hline \multirow[t]{2}{*}{ Guiding interview topics } & \multirow[t]{2}{*}{ Aggregated statements } & \multicolumn{20}{|c|}{ Confirmations from actors (ID 1-20) } \\
\hline & & 1 & 2 & 3 & 4 & 5 & 6 & 7 & 8 & 9 & 10 & 11 & 12 & 13 & 14 & 15 & 16 & 17 & 18 & 19 & 20 \\
\hline $\begin{array}{l}\text { Correctness of the original } \\
\text { answers to the quantitative } \\
\text { SNA questionnaires }\end{array}$ & Responses were correct & $\mathrm{x}$ & $\mathrm{x}$ & $\mathrm{x}$ & $\mathrm{x}$ & $\mathrm{x}$ & $\mathrm{x}$ & $\mathrm{x}$ & $\mathrm{x}$ & $\mathrm{x}$ & $\mathrm{x}$ & $\mathrm{x}$ & $\mathrm{x}$ & $\mathrm{x}$ & $\mathrm{x}$ & $\mathrm{x}$ & $\mathrm{x}$ & $\mathrm{x}$ & $\mathrm{x}$ & $\mathrm{x}$ & $\mathrm{x}$ \\
\hline \multirow{4}{*}{$\begin{array}{l}\text { Focus, reasons, and relevance } \\
\text { of collaborations }\end{array}$} & Product development & & $\mathrm{x}$ & $\mathrm{x}$ & $\mathrm{x}$ & $\mathrm{x}$ & $\mathrm{x}$ & $\mathrm{x}$ & $\mathrm{x}$ & $\mathrm{x}$ & & $\mathrm{x}$ & $\mathrm{x}$ & & $\mathrm{x}$ & $\mathrm{x}$ & $\mathrm{x}$ & $\mathrm{x}$ & $\mathrm{x}$ & $\mathrm{x}$ & $\mathrm{x}$ \\
\hline & Marketing and promotion & $\mathrm{x}$ & $\mathrm{x}$ & $\mathrm{x}$ & $\mathrm{X}$ & $\mathrm{X}$ & & $\mathrm{x}$ & $\mathrm{x}$ & $\mathrm{x}$ & $\mathrm{x}$ & $\mathrm{X}$ & $\mathrm{x}$ & $\mathrm{x}$ & & $\mathrm{x}$ & $\mathrm{x}$ & $\mathrm{x}$ & $\mathrm{x}$ & $\mathrm{x}$ & $\mathrm{x}$ \\
\hline & Get information exchange & $\mathrm{x}$ & $\mathrm{x}$ & $\mathrm{x}$ & $\mathrm{x}$ & & $\mathrm{X}$ & $\mathrm{x}$ & $\mathrm{x}$ & & $\mathrm{x}$ & $\mathrm{x}$ & $\mathrm{x}$ & $\mathrm{x}$ & $\mathrm{x}$ & $\mathrm{x}$ & $\mathrm{x}$ & $\mathrm{x}$ & $\mathrm{x}$ & & $\mathrm{x}$ \\
\hline & Adaptation to climate change & $\mathrm{x}$ & $\mathrm{x}$ & & $\mathrm{x}$ & $\mathrm{x}$ & & & $\mathrm{x}$ & & & $\mathrm{x}$ & & & $\mathrm{x}$ & & $\mathrm{x}$ & $\mathrm{x}$ & & $\mathrm{x}$ & \\
\hline \multirow{5}{*}{$\begin{array}{l}\text { Perception of own network } \\
\text { position within the } \\
\text { community/region }\end{array}$} & According to metrics interpretation & $\mathrm{x}$ & $\mathrm{x}$ & & & & & $\mathrm{x}$ & $\mathrm{x}$ & & & & $\mathrm{x}$ & & & - & & & & & $\mathrm{x}$ \\
\hline & Estimated more central & & & & & & & $\mathrm{X}$ & & & & & & & $\mathrm{X}$ & $\mathrm{x}$ & & $\mathrm{X}$ & $\mathrm{X}$ & $\mathrm{X}$ & \\
\hline & Estimated less central & $\mathrm{x}$ & & & $\mathrm{x}$ & $\mathrm{x}$ & $\mathrm{x}$ & & & & $\mathrm{x}$ & $\mathrm{x}$ & $\mathrm{x}$ & & & & & & & & \\
\hline & Brokering function & $\mathrm{x}$ & & & $\mathrm{x}$ & & & & $\mathrm{x}$ & & & & & & & & $\mathrm{x}$ & & & & \\
\hline & Satisfaction with their position & $\mathrm{x}$ & $\mathrm{x}$ & $\mathrm{x}$ & $\mathrm{x}$ & $\mathrm{x}$ & $\mathrm{x}$ & & $\mathrm{x}$ & $\mathrm{x}$ & & $\mathrm{x}$ & $\mathrm{x}$ & $\mathrm{x}$ & & $\mathrm{x}$ & - & - & & - & - \\
\hline \multirow{7}{*}{$\begin{array}{l}\text { State of perceived } \\
\text { intercommunity collaboration } \\
\text { in the region }\end{array}$} & $\begin{array}{l}\text { Lack of collaboration between } \\
\text { Sedrun and Disentis }\end{array}$ & $\mathrm{x}$ & & $\mathrm{x}$ & $\mathrm{x}$ & & & & & & $\mathrm{x}$ & & & & & $\mathrm{x}$ & & & & & \\
\hline & $\begin{array}{l}\text { Lack of collaboration between } \\
\text { Disentis and Andermatt }\end{array}$ & $\mathrm{x}$ & & $\mathrm{x}$ & & $\mathrm{x}$ & $\mathrm{x}$ & $\mathrm{x}$ & $\mathrm{x}$ & $\mathrm{x}$ & $\mathrm{x}$ & & $\mathrm{x}$ & & $\mathrm{x}$ & $\mathrm{x}$ & & $\mathrm{x}$ & & & \\
\hline & $\begin{array}{l}\text { Lack of collaboration because of } \\
\text { geographical/political reasons }\end{array}$ & $\mathrm{x}$ & $\mathrm{x}$ & $\mathrm{x}$ & $\mathrm{x}$ & $\mathrm{x}$ & $\mathrm{x}$ & & $\mathrm{x}$ & $\mathrm{x}$ & $\mathrm{x}$ & $\mathrm{x}$ & $\mathrm{x}$ & & $\mathrm{x}$ & $\mathrm{x}$ & & & $\mathrm{x}$ & & $\mathrm{x}$ \\
\hline & $\begin{array}{l}\text { Lack of orientation with Disentis } \\
\text { actors }\end{array}$ & $\mathrm{x}$ & & $\mathrm{x}$ & & $\mathrm{x}$ & & & & & & $\mathrm{x}$ & & & $\mathrm{x}$ & & & & & & \\
\hline & Lock-in effect & & & & & & & & & & $\mathrm{X}$ & $\mathrm{X}$ & $\mathrm{x}$ & $\mathrm{x}$ & $\mathrm{x}$ & $\mathrm{x}$ & $\mathrm{x}$ & $\mathrm{x}$ & $\mathrm{x}$ & & \\
\hline & Brokering function of Sedrun & $\mathrm{x}$ & $\mathrm{x}$ & $\mathrm{x}$ & $\mathrm{x}$ & $\mathrm{x}$ & $\mathrm{x}$ & & $\mathrm{x}$ & $\mathrm{x}$ & & $\mathrm{x}$ & $\mathrm{x}$ & $\mathrm{x}$ & & $\mathrm{x}$ & & & $\mathrm{x}$ & & $\mathrm{x}$ \\
\hline & $\begin{array}{l}\text { A regional DMO will improve } \\
\text { collaboration }\end{array}$ & $\mathrm{x}$ & $\mathrm{x}$ & $\mathrm{x}$ & & $\mathrm{x}$ & & $\mathrm{x}$ & $\mathrm{x}$ & & $\mathrm{x}$ & & $\mathrm{x}$ & $\mathrm{x}$ & $\mathrm{x}$ & $\mathrm{x}$ & $\mathrm{x}$ & $\mathrm{x}$ & $\mathrm{x}$ & $\mathrm{x}$ & $\mathrm{x}$ \\
\hline \multirow[t]{5}{*}{$\begin{array}{l}\text { Quality and motivation of } \\
\text { collaboration }\end{array}$} & $\begin{array}{l}\text { Demotivating if collaborations are } \\
\text { not successful or unpleasant }\end{array}$ & $\mathrm{x}$ & $\mathrm{x}$ & $\mathrm{x}$ & & $\mathrm{x}$ & $\mathrm{x}$ & $\mathrm{x}$ & $\mathrm{x}$ & $\mathrm{x}$ & $\mathrm{x}$ & $\mathrm{x}$ & $\mathrm{x}$ & $\mathrm{x}$ & $\mathrm{x}$ & $\mathrm{x}$ & & $\mathrm{x}$ & & $\mathrm{x}$ & \\
\hline & Others do not value one's relevance & & & & & $\mathrm{x}$ & $\mathrm{x}$ & & & $\mathrm{x}$ & & & & & & $\mathrm{x}$ & & & & & \\
\hline & Lack of time and resources & & & & & & & & & & $\mathrm{x}$ & $\mathrm{x}$ & & & & $\mathrm{x}$ & & & & & \\
\hline & $\begin{array}{l}\text { Fear of collaboration for } \\
\text { competitiveness }\end{array}$ & & & & & $\mathrm{x}$ & & & $\mathrm{x}$ & & $\mathrm{x}$ & & & & & & & & & & \\
\hline & $\begin{array}{l}\text { Some people are jealous of other } \\
\text { actors' collaborations/position }\end{array}$ & $\mathrm{x}$ & $\mathrm{x}$ & & & & & & & & & $\mathrm{x}$ & $\mathrm{x}$ & & & & & & & & \\
\hline \multirow{3}{*}{$\begin{array}{l}\text { Expectations on development } \\
\text { of collaborations for the } \\
\text { future }\end{array}$} & Intensify collaborations & - & $\mathrm{x}$ & $\mathrm{x}$ & $\mathrm{x}$ & - & $\mathrm{x}$ & $\mathrm{x}$ & $\mathrm{x}$ & & $\mathrm{x}$ & & - & $\mathrm{x}$ & $\mathrm{x}$ & $\mathrm{x}$ & $\mathrm{x}$ & $\mathrm{x}$ & $\mathrm{x}$ & $\mathrm{x}$ & $\mathrm{x}$ \\
\hline & Collaborate more with Andermatt & $\mathrm{x}$ & $\mathrm{x}$ & & $\mathrm{x}$ & & & & & & & & & & & & & & $\mathrm{x}$ & & \\
\hline & $\begin{array}{l}\text { Collaborate more with more central } \\
\text { actors }\end{array}$ & $\mathrm{x}$ & & & & $\mathrm{x}$ & $\mathrm{x}$ & & & $\mathrm{x}$ & & $\mathrm{x}$ & & & & & & & & & \\
\hline \multirow[t]{3}{*}{$\begin{array}{l}\text { Plans for (climate change) } \\
\text { adaptation and development }\end{array}$} & $\begin{array}{l}\text { Development of new services and } \\
\text { products }\end{array}$ & $\mathrm{x}$ & & & & & & $\mathrm{x}$ & $\mathrm{x}$ & & & $\mathrm{x}$ & $\mathrm{x}$ & & & $\mathrm{x}$ & $\mathrm{x}$ & & $\mathrm{x}$ & $\mathrm{x}$ & \\
\hline & Generate ideas in collaboration & $\mathrm{X}$ & & & & $\mathrm{x}$ & & $\mathrm{x}$ & $\mathrm{x}$ & $x$ & & $\mathrm{X}$ & $\mathrm{x}$ & & $\mathrm{x}$ & $\mathrm{X}$ & $\mathrm{x}$ & $\mathrm{x}$ & $\mathrm{x}$ & $\mathrm{x}$ & \\
\hline & Focus on winter and snow making & $\mathrm{x}$ & & & $\mathrm{x}$ & & & & & & & & & & & & $\mathrm{x}$ & & & & \\
\hline
\end{tabular}

approach described in the Methods section, we found the highest core-periphery integration in Andermatt because modularity was negative and the lowest $(-0.0397$, Table 2$)$. The DMO coreperiphery integration ranked second (-0.007) and was considerably higher than in Sedrun (0.0314) and in Disentis (0.0175): Sedrun and Disentis, and thus the region comprising all three municipalities, benefited from a better core-periphery integration in a planned DMO. Figure 3 shows the core-periphery integration in the municipalities and their cross-scale integration on the regional DMO scale.
Cross-scale governance integration

Regarding the integration of the three municipalities in the planned regional DMO, we found a lack of collaboration between actors from Andermatt and Disentis. Actors from Sedrun brokered between the two other municipalities (Figs. 3 and 4). Actors in all three municipalities are well connected to their main brokers (indicated by their highest betweenness centrality) in the same municipality, supporting municipal core-peripheral integration. On the regional scale, actors from Andermatt and Disentis sought more collaboration with the brokers from Sedrun and less with each other: although the brokers of Disentis and 
Fig. 3. The destination management organization (DMO) network both in a force-directed layout (left) and in a clustering layout (right) colored by the three municipalities, sized by actors of the core (bigger nodes) and of the periphery (smaller nodes), and labeled by the tourism supply chain sectors (http://www.mappr.io).
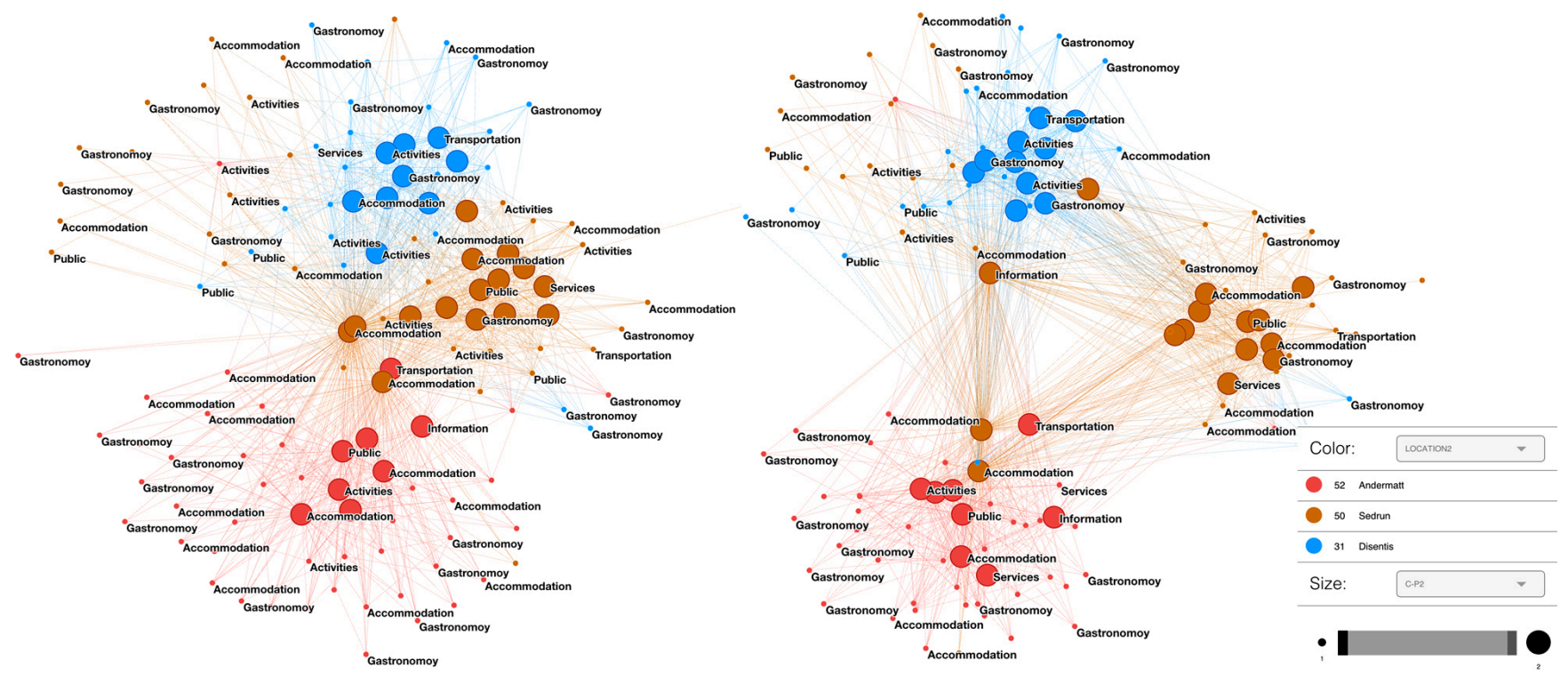

Andermatt merely connected their municipalities with each other, the brokers of Sedrun bridged both Andermatt and Disentis (Fig. 4). The municipal integration in the regional DMO existed, but new ties between Andermatt and Disentis would need to be developed with the help of the Sedrun brokers to improve integration.

\section{Clustering}

The clustering coefficient was lower in the regional DMO than in the municipalities, which accounted for a potentially lower amount of information flow in the DMO than in the municipalities (Table 1). This supported the tendency for lower collaboration effects in the DMO indicated by the differences in the network densities. Within the municipalities, the highest clustering and thus the highest flow of information were found in Andermatt. On the municipal governance scale, the inclusion of actors for collective action especially regarding sudden changes was better than in the DMO, supporting aim (2) of a resilient governance structure as discussed before: reacting to short-term shocks demands quick distribution of information and centralized steering of collective action.

\section{Average path length}

The average path length was longer in the DMO than in the municipalities, indicating a slower flow of information on the regional governance scale than on the municipal scale. Reactions to sudden changes could be best dealt with on the municipal scale.

\section{Global and local efficiency}

The network measure of efficiency indicated the capability for exchanging information on a full network (global efficiency) level, and on an actor (local efficiency) level. At a global level, Disentis had the highest efficiency for distributing information, followed by Sedrun, the DMO, and Andermatt. At a local level (average of nodal efficiencies), actors in Andermatt had the highest efficiency, followed by Sedrun, the DMO, and Disentis, which were all quite similar. Governance on the regional DMO scale improved the distribution of information on the network level in the case of Andermatt, while the DMO offered no improved information exchange on a local level.

\section{INTERVIEWS AND GROUP DISCUSSIONS}

The interviewees (Fig. 2) confirmed the overall accuracy of the responses provided in the quantitative SNA questionnaires when they were confronted with the coded sheets they had filled out. The main structure and aggregated results of the interviews are summarized in Table 4. Half of the interviewees saw adaptation to climate change as a driving force for collaboration in the region, while 13 actors mentioned the generation of ideas for adaptation and overall innovation in a collaborative setting. Other motivators for collaboration were product development, marketing, and general information exchange.

The majority of actors were not aware of their network position in the municipalities and the region, and a network-based conceptual thinking of centrality in relation to other actors from the tourism supply chain sector was new to most. The most central actors were aware of their general importance in the region and were satisfied with their perceived positions, though they expected their positions to be less central when confronted with the network graphs. The less central actors were rather overestimating their centralities, and the least central or peripheral and isolated actors were not satisfied with their low centrality when their network positions were revealed (Table 4).

The more peripheral actors in all three municipalities perceived a lock-in situation whereby they felt excluded from the development of the tourism sector in the region and felt neglected or actively suppressed by more central tourism actors. This confirms the centrality measures emanating from the network 
Fig. 4. Cross-scale governance integration of the municipalities on the regional destination management organization (DMO) scale with the most betweenness-central nodes (brokers) of each municipality and their ties highlighted. The brokers of Sedrun bridge between Disentis and Andermatt that otherwise lack collaboration (http://www.mappr.io).

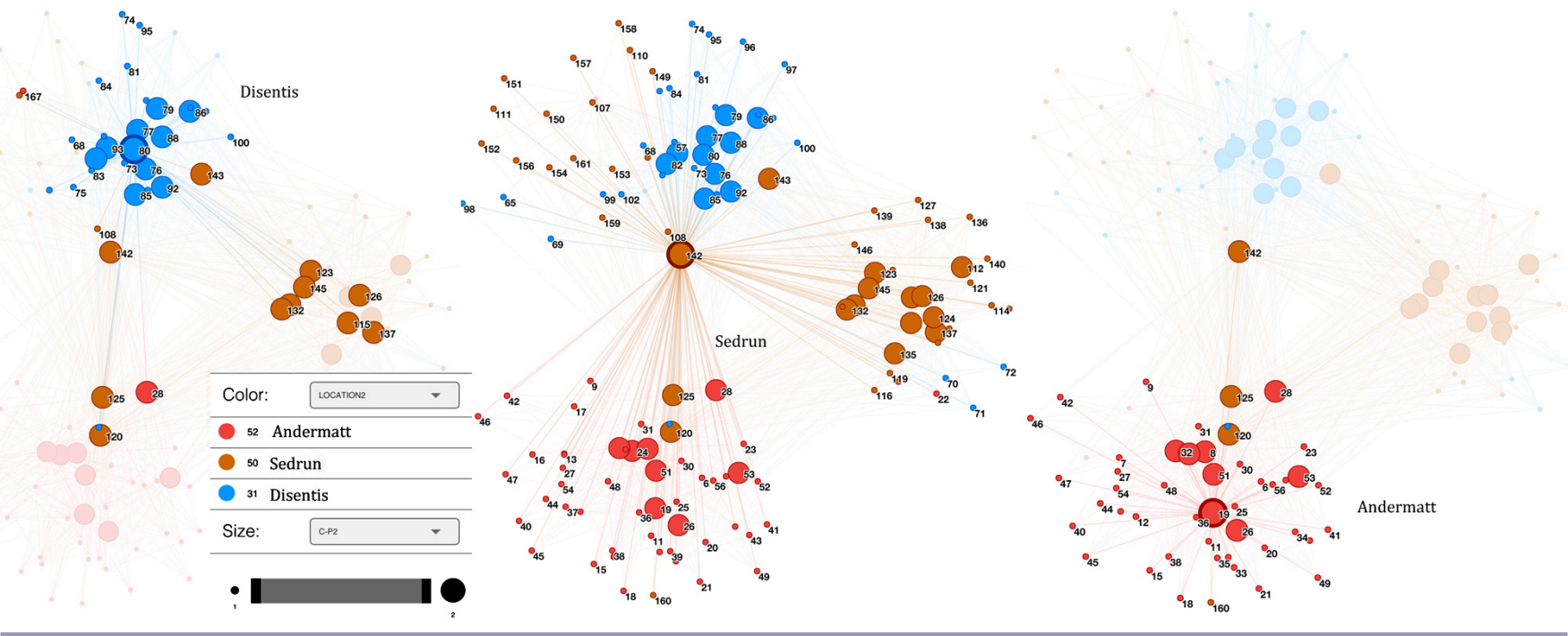

analysis. In addition, peripheral or isolated actors mentioned that they feared collaborating for competitive reasons. Other interviewees brought up the fact that some actors still remained in patterns of thought from a time when tourism in the region was flourishing and the need for collaboration was less pressing and obvious. Rivalry and a lack of personal and financial resources were stated as other important barriers to stronger collaboration.

The lack of integration between the three municipalities was confirmed in the interviews. The tension in the region, especially between actors from Sedrun and Disentis and between actors from Andermatt and Disentis linked to the developments in Andermatt mentioned earlier, and because of the geographical and political borders, was acknowledged. The situation of collaboration between the three single destinations was perceived to be very dynamic, having changed considerably with the recent resort development in Andermatt. The development of new ties between Andermatt and Disentis was understood to be difficult because of the new functional closeness between Sedrun and Andermatt. Most interviewed actors were aware of the brokering function of Sedrun in the region, both between Andermatt and Disentis, and between the cantons of Uri and Grisons. Actors understood this brokering position as being beneficial to them. Several actors from Andermatt mentioned that actors from Disentis lack (strategic) orientation in terms of choosing collaboration partners. No actor from Disentis or Sedrun mentioned this uncertainty. It seems that these barriers for collaboration were just perceived by actors from Andermatt. Another important barrier for improving overall collaboration and integration is the lack of human resources to intensify collaboration. Interviewees acknowledged the need to increase and improve collaboration in the region but expressed personal and organizational restrictions because of limited time resources to actively develop new ties. Only some of the most central actors did not see the potential or necessity for more collaboration because they felt saturated. Most actors saw the implementation of a managing body within the planned regional DMO as being an instrument to potentially improve overall collaboration in the region.

\section{SYNTHESIS AND DISCUSSION}

The properties of the analyzed networks indicated a more resilient governance structure of the DMO if municipalities were integrated on the regional scale. The larger DMO network with a higher diversity of ties had a higher modularity and a higher global efficiency and was thus better equipped to support social learning and innovation for responding to aim (1), innovative capacity. The smaller municipal networks were better equipped for fast collective action and responding to quick challenges, aim (2), adaptive capacity, because of a lower modularity, a higher cohesion, a higher local efficiency, and a shorter average path length, which all supported the distribution of information. The DMO combined the municipal properties to a more centralized and more modular, larger network, with better core-periphery integration, thus supporting both aims (1) and (2) of a resilient tourism SES governance structure. This was in accordance with the literature that tourism systems governed on a higher scale tend to be more resilient (Beritelli et al. 2007). It confirmed the literature in the sense that general SES at higher organizational scales tend to be more efficient in resource use and find more comprehensive approaches to equity-beneficial for social learning - but may be unable or too slow to cope with local variations and specifications (Young 2002, Walker et al. 2004). Beyond this, governance on an even higher, global scale incorporates new challenges of extreme size and complexity (Ostrom 1990).

The interpretation of resilience based on the presented network metrics was qualitatively confirmed in the personal interviews and in the ClimAlpTour workshop (Luthe et al. 2012), among them the overall lack of collaboration, the specific lack of ties between 
Table 5. Summary of the interpretation of the quantitative results (based on Table 1) and their qualitative validation from interviews and the workshop. DMO indicates destination management organization.

\begin{tabular}{lll}
\hline \hline Network metric & Interpretation of quantitative results & Qualitative validation \\
\hline Size & $\begin{array}{l}\text { Regional DMO network is more resilient because it } \\
\text { combines the quicker responsiveness of smaller } \\
\text { community networks with overall better integration, } \\
\text { steering of collective action, and long-term }\end{array}$ & $\begin{array}{l}\text { Confirmed by perceived necessity of regional DMO } \\
\text { network to integrate and steer smaller community } \\
\text { networks. }\end{array}$
\end{tabular}

Density

Average degree

Betweenness centrality

Modularity index Q

Clustering coefficient

Average path length

Efficiency transformation.

General tendency to cooperate within rather than between communities leads to overall lower density of the regional DMO. The lack of collaboration between

Andermatt and Disentis is the main weakness in the region.

DMO with a higher average degree has strengths in steering collective action but may lead to lock-in effects when central actors control the network, thus possibly suppressing the uptake of new ideas. Because the integration of the communities and core-periphery integration in DMO are improved, the disadvantages of higher centralization regarding a potential lock-in effect may be outweighed.

Sedrun actors have the highest betweenness centrality, indicating their broker function in the network, supporting the importance of Sedrun to increase regional collaboration, i.e., between Andermatt and Disentis once a DMO is in place.

Today regional collaboration is perceived as low, and a DMO is expected to improve cross-scale collaboration. Actors perceive a lock-in effect in the communities where new ideas are not being picked up. They expect a planned DMO to strengthen integration between communities and core-peripheral networks, and this may buffer a potential lock-in effect because of the development of new ties.

Perceived lack of trust between Andermatt and Disentis and historic reasons confirm the lack of ties. Sedrun actors are seen as the ones having best contacts to both Andermatt and Disentis and confirm the broker interpretation of high betweenness centrality.

From a positive angle, modularity is higher in DMO than in communities and thus indicates a higher innovative capacity of the DMO. From a negative angle, this hinders collaboration because of strong bonds within the subgroups; because overall modularity is relatively low, this effect is rather weak.

Lower clustering in the DMO means lower amount and (possibly) speed of information flow, higher clustering in the communities means higher amount and (possibly) speed of information flow.

Information flow in the DMO is slower than in the communities, but good integration of the communities can outweigh this effect. Quick action is more likely to take place in the communities.

Faster flow of information in the communities, slower in the planned DMO as of today, supporting the findings from average path length.
Actors perceive that a regional DMO would improve innovation by more collaboration between actors with similar interests and access to more diverse actors.

Actors focus on collaboration within the communities addressing short-term needs because of faster, more direct, and personal communication.

Actors focus on collaboration within the communities addressing short-term needs because of faster, more direct, and personal communication.

Actors focus on collaboration within the communities addressing short-term needs because of faster, more direct, and personal communication.
Andermatt and Disentis, the brokering function of actors from Sedrun, the lock-in effect of regional core actors not integrating peripheral actors and their innovative capacities, and actor centrality positions (see Table 4). The main regional weakness identified in the network topology, i.e., a lack of municipal integration based on a lack of collaborative ties between Andermatt and Disentis, was also expressed and confirmed by stakeholders in the interviews and in the workshops. The need for strengthened brokering by actors from Sedrun between both Andermatt and Disentis becomes even more important to increase resilience in the region (Table 4).

The comparison of centrality measures indicates signs of higher resilience of the DMO at the regional governance scale in coping with more gradual and complex changes, and of the individual municipalities at the municipal scale in coping with more sudden changes. The planned DMO shows more centralized and more centrally steered network properties than the individual municipalities, with advantages for clearly directed collective actions. Central actors can therefore make their concerns better heard and actively steer governance processes to react to both gradual changes and more sudden changes, which require fast collective adaptation actions. The potentially hindering effects of the higher centralization for innovation due to potential lock-in effects may be balanced out by the lower density, supporting the distribution of more inhomogeneous, unconventional ideas (Table 5). The high DMO centralization may in addition enhance the adoption and implementation of innovative ideas introduced from the network periphery. Interviewees' perceptions confirm that a DMO would likely strengthen integration through more centralized steering of action.

The individual municipalities are more cohesive, denser, have shorter path lengths, and higher local efficiencies. This leads to a 
higher level of information-sharing and a faster flow of information between the actors, which relates to a generally higher overall ratio of collaboration. In comparison to the DMO, this allows the municipalities to better react to sudden changes requiring fast collective action for rather simple solutions, such as clearing a road from an avalanche. Central coordination can outperform decentralized information distribution regarding simple challenges or solutions, but the advantage of centrally steering collective action shrinks with the complexity of the problem (Berardo and Scholz 2010). Thus, a larger DMO network benefits from the existence and integration of its meso-scale structure to serve both aims of (1) preparing for gradual changes by innovation, and (2) responding to sudden changes by quick adaptive actions.

Based on the higher modularity measures, the DMO has a higher potential for innovative capacity and social learning than the individual municipalities. It is thus potentially better equipped to cope with vague and gradually developing challenges, requiring a transformation of the regional tourism economy. The interviews and stakeholder workshops confirm that the mainstreaming of ideas may lead to a lock-in situation. Participants of lower regional centrality and from the periphery of the network reported their experiences that innovative ideas, especially from more peripheral actors, were actively suppressed by central actors within the region, as experienced in various public gatherings. The integration of the core with the periphery is best developed in Andermatt, followed by the DMO. Both Disentis and Sedrun would gain in core-periphery integration by the development of a DMO.

In this context, the development of the regional DMO could counteract the lack of integration between Andermatt and Disentis by building upon the already existing brokering role of actors from Sedrun. The recent interest of certain actors from Sedrun toward the new resort development in Andermatt creates tension in the region, and more specifically between actors from Sedrun and Disentis, and from Disentis and Andermatt. The identified lack of ties between Andermatt and Disentis has partly historical roots because there has been a history of close collaboration between Sedrun and Disentis but not with Andermatt because of geographic and political isolation (Oberalp pass and cantonal borders). In a regional DMO context, Sedrun takes over the role of a broker between Andermatt and Disentis to form new ties, confirmed by the perceptions of interviewees from all municipalities. It is difficult to foresee whether the Sedrun brokering function will be strong enough to outweigh the recent lack of trust (and ties) between actors from Disentis and Sedrun and to outweigh the barriers regarding the development of new ties between Andermatt and Disentis.

The development of the DMO would increase resilience of the individual municipalities and thus the region, especially in reacting to more complex and gradual changes, requiring collective action, innovation, mitigation, and transformation. A potential structural weakness of the DMO would lie in the general low level of collaborative ties between tourism actors from all three municipalities, as well as the structure-inherent danger of lock-in effects, because of the high degree of centralization. To address this problem, the managing body of the planned DMO would need to function as an enabler, facilitating collaboration and specifically core-periphery integration in exchanging innovative ideas.

Limitations of the analysis in this paper are for one the lack of displaying dynamics of social networks: although a single SNA can only capture a snapshot of a collaborative network, effects over time may influence a resilience assessment that was done based on a single dataset in time. First, some ties may exist but were not visible in our analysis because they are activated only under the influence of certain stressors. Longitudinal studies over time and accompanying qualitative work and observations might help to address such weaknesses. Second, the interpretation of metrics is purely based on the quantity or (non)existence of ties, but the quality of ties, whether they are strong or weak, may influence interpretations. Positive ties may be regarded as strong and well-functioning, being frequently activated and thus productive, whereas negative ties may be understood as weak and less frequently activated, thus less productive. Third, a degree of uncertainty remains with regard to the possible generalization of the interpretations of network metrics in the context of climate change resilience and how scale and/or context could be better integrated into the resilience assessment of (tourism) SES governance structures. Fourth, sharing information is not only a structural diffusion process, but also subject to personal and institutional fit, because structure and function of ties are intertwined (Bergsten et al. 2014, Lubell et al. 2014).

Additional research will be important to allow for an evaluation of the robustness of the results presented here, with regard to similar SES in the same or in other climatic and geographical contexts. The assumed effects of a better core-periphery integration at a regional (DMO) scale and the higher innovative capacity should be empirically retraced once the respective organizational structures are in place. Overall, the combined methodological approach presented in this paper enables a quantitative and qualitative validation of literature-based resilience interpretation, a promising approach for future studies.

\section{CONCLUSIONS}

In this paper we contribute to the resilience discussion with (1) the interpretation of network metrics for resilience based on a comparative network analysis of tourism SES on different governance scales, by (2) integrating and empirically validating such network metrics with qualitative data, to (3) provide policy implications for tourism management.

Network metrics indicate higher resilience of the SurselvaGotthard tourism system at the regional DMO governance scale compared with the municipal governance scale. In the planned DMO, the advantages of the municipalities are combined with the advantages of actors being part of a larger network. The DMO regional network is better equipped to steer governance processes that require collective action. It has a higher structural innovative capacity, allowing the system to cope with more complex, slower, and gradual aspects of climate change that require mitigation and innovation by social learning, including structural changes. Adaptation to the generally slower developing trends and impacts of climate change, which require innovation, diversification of products, services, seasonal offers, mitigation, and more structural transformation, should therefore be organized at the DMO governance scale. The individual municipalities can cope better with fast, sudden climate change impacts. Adaptation to 
immediate shocks and fast variations of climate change, such as extreme events or short-term trends, should be organized and steered at the municipal governance scale. This also allows for testing of alternative responses in the different municipalities, such as, for instance, new snow-independent activities, as a response to changing consumer demand in times of climate change. The overall validation is concluded with care because we could not rely on longitudinal data, but available qualitative data allows for the in-depth understanding of the underlying social processes in the analyzed SES and supports the interpretations, because context dependency is highly important for resilience.

Qualitative data from 20 interviews and one workshop with stakeholders from the same sample confirm the metrics and their interpretation for resilience. Higher resilience of the planned regional DMO network is qualitatively confirmed by stakeholder perceptions and expectations. Stakeholders demand the establishment of a DMO and expect it to enable better spatial and structural collaboration of actors between the individual municipalities. Interviewees believe that such improved collaboration will be achieved by developing new ties between Andermatt and Disentis with the support of the brokering actors from Sedrun. Interviews confirm the existence of a core and a periphery of actors through a reported lock-in effect and differences in the number of collaboration partners. Once established, the DMO as a management organization will need to take specific care of preventing further lock-in effects.

The governance of a tourism SES at a regional scale rather than at a municipal scale increases resilience in the case of the Swiss Surselva-Gotthard region because of the existing multi- and cross-scale integration combining network properties that are better governed on a regional scale (aim 1 - innovative capacity) and on a municipal scale (aim 2 - adaptive capacity). This may support the formation of new DMOs in tourism dependent regions and of similar governance networks in other industries. To increase overall resilience in a region, the formation of new organizations at a higher governance scale can be beneficial, as long as integration is assured across and within scales and coreto-periphery, and lock-in effects because of higher, otherwise positive, centralization can be controlled.

The functional (management) consequences with respect to increasing resilience of the analyzed governance networks are the development of new ties to improve overall collaboration, an increase of network density, for example, by institutionalized networking projects, and further strengthening of core-peripheral and regional municipal integration via the support and engagement of the brokers present in the region. The unveiled uncertainty for collaborative strategic development and the perceived lock-in effect in the region require a facilitator or enabler, a role the new Gotthard DMO as a management organization could take over. The new Gotthard DMO may thus be of specific importance as a governing body supporting collaboration and integration, and overall resilience of the region.

Further research may look at the quality and the functioning of existing ties. Such analyses that distinguish the quality from the quantity of ties may influence the assessment and interpretation of resilience based on the existence of ties. Further research may also compare different regions, pursue research at a global level, and monitor the development of such networks over time.
Responses to this article can be read online at: http://www.ecologyandsociety.org/issues/responses. php/8234

\section{Acknowledgments:}

We acknowledge funding from the Swiss Network of International Studies (SNIS) and from the Interreg Alpine Space program. Special thanks goes to Eric L. Berlow from Vibrant Data Labs for support in visualizing networks with the software mapprio. We furthermore acknowledge support in the qualitative interviews by the former Master student Katja Schneider and proof reading by Jan Mosedale, and are grateful for the comments of anonymous reviewers.

\section{LITERATURE CITED}

Abrahamson, E., and L. Rosenkopf. 1997. Social network effects on the extent of innovation diffusion: a computer simulation. Organization Science 8(3):289-309. http://dx.doi.org/10.1287/ orsc.8.3.289

Adaic, L. A., and E. Adar. 2003. Friends and neighbors on the web. Social Networks 25:211-230. http://dx.doi.org/10.1016/ S0378-8733(03)00009-1

Ahn, B. Y., B. K. Lee, and C. S. Shafer. 2002. Operationalizing sustainability in regional tourism planning: an application of the limits of acceptable change framework. Tourism Management 23:1-15. http://dx.doi.org/10.1016/S0261-5177(01)00059-0

Allison, H. E., and R. J. Hobbs. 2004. Resilience, adaptive capacity, and the "Lock-in Trap" of the western Australian agricultural region. Ecology and Society 9(1):3. [online] URL: http://www.ecologyandsociety.org/vo19/iss1/art3/

Asheim, B. T., and A. Isaksen. 1997. Location, agglomeration and innovation: towards regional innovation systems in Norway? European Planning Studies 5(3):299-330. http://dx.doi. org/10.1080/09654319708720402

Baggio, R. 2011. Collaboration and cooperation in a tourism destination: a network science approach. Current Issues in Tourism 14(2):183-189. http://dx.doi.org/10.1080/13683500.2010.531118

Baggio, R., N. Scott, and C. Cooper. 2010a. Improving tourism destination governance: a complexity science approach. Tourism Review 65(4):51-60. http://dx.doi.org/10.1108/16605371011093863

Baggio, R., N. Scott, and C. Cooper. 2010b. Network science: a review focused on tourism. Annals of Tourism Research 37 (3):802-827. http://dx.doi.org/10.1016/j.annals.2010.02.008

BAK Basel Economic Research \& Consulting. 2006. Tourismus Benchmark Studie für Graubünden. Schlussbericht. BAK Basel Economic Research \& Consulting, Basel, Switzerland.

Bastian, M. 2009. Gephi: an open source software for exploring and manipulating networks. Third International A A AI Conference on Weblogs and Social Media. AAAI Publications, Palo Alto, California, USA.

Becken, S. 2013. Developing a framework for assessing resilience of tourism sub-systems to climatic factors. Annals of Tourism Research 43:506-528. http://dx.doi.org/10.1016/j.annals.2013.06.002 
Beniston, M. 2007. Entering into the "greenhouse century": recent record temperatures in Switzerland are comparable to the upper temperature quantiles in a greenhouse climate. Geophysical Research Letters 34(16). http://dx.doi.org/10.1029/2007gl030144

Berardo, R., and J. T. Scholz. 2010. Self-organizing policy networks: risk, partner selection, and cooperation in estuaries. American Journal of Political Science 54(3):632-649. http://dx. doi.org/10.1111/j.1540-5907.2010.00451.x

Bergsten, A., D. Galafassi, and Ö. Bodin. 2014. The problem of spatial fit in social-ecological systems: detecting mismatches between ecological connectivity and land management in an urban region. Ecology and Society 19(4):6. http://dx.doi. org/10.5751/es-06931-190406

Beritelli, P. 2011. Cooperation among prominent actors in a tourist destination. Annals of Tourism Research 38(2):607-629. http://dx.doi.org/10.1016/j.annals.2010.11.015

Beritelli, P., T. Bieger, and C. Laesser. 2007. Destination governance: using corporate governance theories as a foundation for effective destination management. Journal of Travel Research 46(1):96-107. http://dx.doi.org/10.1177/0047287507302385

Beritelli, P., T. Bieger, and C. Laesser. 2013b. The new frontiers of destination management: applying variable geometry as a function-based approach. Journal of Travel Research 53 (4):403-417.

Beritelli, P., A. Strobl, and M. Peters. 2013a. Interlocking directorships against community closure: a trade-off for development in tourist destinations. Tourism Review 68(1):21-34. http://dx.doi.org/10.1108/16605371311310057

Biggs, D. 2011. Understanding resilience in a vulnerable industry: the case of reef tourism on Australia. Ecology and Society 16 (1):30. [online] URL: http://www.ecologyandsociety.org/vol16/ iss $1 / \operatorname{art} 30 /$

Blondel, V. D., J.-L. Guillaume, R. Lambiotte, and E. Lefebvre. 2008. Fast unfolding of communities in large networks. Journal of Statistical Mechanics: Theory and Experiment P10008. http:// dx.doi.org/10.1088/1742-5468/2008/10/p10008

Boccaletti, S., V. Latora, Y. Moreno, M. Chavez, and D.-U. Hwang. 2006. Complex networks: structure and dynamics. Physics Reports 424:175-308. http://dx.doi.org/10.1016/j. physrep.2005.10.009

Bodin, Ö., and B. I. Crona. 2009. The role of social networks in natural resource governance: What relational patterns make a difference? Global Environmental Change 19(3):366-374. http:// dx.doi.org/10.1016/i.gloenvcha.2009.05.002

Bodin, Ö., B. Crona, and H. Ernstson. 2006. Social networks in natural resource management: What is there to learn from a structural perspective? Ecology and Society 11(2):r2. [online] URL: http://www.ecologyandsociety.org/vol11/iss2/resp2/ http:// dx.doi.org/10.1017/cbo9780511894985

Borgatti, S. P., and M. G. Everett. 2000. Models of core/periphery structures. Social Networks 21(4):375-395. http://dx.doi. org/10.1016/s0378-8733(99)00019-2
Borgatti, S. P., M. G. Everett, and L. C. Freeman. 2002. Ucinet for Windows: software for social network analysis. Analytic Technologies, Harvard, Massachusetts, USA.

Bramwell, B., and A. Sharman. 1999. Collaboration in local tourism policymaking. Annals of Tourism Research 26 (2):392-415. http://dx.doi.org/10.1016/S0160-7383(98)00105-4

Brandes, U., and D. Wagner. 2004. Visone - analysis and visualization of social networks. Pages 321-340 in M. Jünger and P. Mutzel, editors. Graph drawing. Springer, Dordrecht, The Netherlands.

Breiger, R. 1981. Structures of economic interdependence among nations. Pages 353-380 in P. M. Blau and R. K. Merton, editors. Continuities in structural inquiry. Sage, Newbury Park, California, USA.

Brosius, H.-B., and F. Koschel. 2001. Methoden der empirischen Kommunikationsforschung. Eine Einführung. Westdeutscher Verlag, Wiesbaden, Germany. http://dx.doi.org/10.1007/978-3-322-95618-7

Burt, R. S. 2004. Structural holes and good ideas. American Journal of Sociology 110(2):349-399. http://dx.doi.org/10.1086/421787

Cattani, G., and S. Ferriani. 2008. A core/periphery perspective on individual creative performance: social networks and cinematic achievements in the Hollywood film industry. Organization Science 19(6):824-844. http://dx.doi.org/10.1287/ orsc. 1070.0350

ClimAlpTour. 2011. ClimAlpTour-climate change and its impact on tourism in the Alpine space. Final project report of the Alpine space interreg project ClimAlpTour. Geografski inštitut Antona Melika ZRC SAZU, Ljubljana, Slovenia.

Clivaz, C., M. Doctor, S. Gessner, L. Ketterer, T. Luthe, M. Schuckert, D. Siegrist, and R. Wyss. 2012. Adaptionsstrategien des Tourismus an den Klimawandel in den Alpen. Ergebnisse des alpenweiten Projekts ClimAlpTour in der Schweiz. Schriftenreihe des Instituts für Landschaft und Freiraum. HSR Hochschule fuer Technik Rapperswil, Rapperswil, Switzerland.

Costa, L. D. F., and R. Baggio. 2009. The web of connections between tourism companies: structure and dynamics. Physica $A$ 388:4286-4296. http://dx.doi.org/10.1016/j.physa.2009.06.034

Costa, L. D. F., F. A. Rodrigues, G. Travieso, and P. R. Villas Boas. 2007. Characterization of complex networks: a survey of measurements. Advances in Physics 56(1):167-242. http://dx.doi. org/10.1080/00018730601170527

Crona, B., and Ö. Bodin. 2006. What you know is who you know? Communication patterns among resource users as a prerequisite for co-management. Ecology and Society 11(2):7. [online] URL: http://www.ecologyandsociety.org/vol11/iss2/art7/

Cross, R., A. Parker, L. Prusack, and S. P. Borgatti. 2001. Knowing what we know: supporting knowledge creation and sharing in social networks. Organizational Dynamics 30 (2):100-120.

Dakos, V., A. Quinlan, J. A. Baggio, E. Bennett, Ö. Bodin, and S. BurnSilver. 2015. Principle 2: manage connectivity. Pages 80-104 
in R. Biggs O., M. Schlüter, and M. L. Schoon, editors. Principles for building resilience: sustaining ecosystem services in socialecological systems. Cambridge University Press, Cambridge, UK. ISBN 978-1-107-08265-6.

Decelle, X. 2006. A dynamic conceptual approach to innovation in tourism. Pages 85-99 in Organisation for Economic Cooperation and Development (OECD), editor. Innovation and growth in tourism. OECD, Paris, France. http://dx.doi. org/10.1787/9789264025028-7-en

Ernstson, H., S. Barthel, E. Andersson, and S. T. Borgström. 2010. Scale-crossing brokers and network governance of urban ecosystem services: the case of Stockholm. Ecology and Society 15(4):28. [online] URL: http://www.ecologyandsociety.org/vol15/ iss $4 / \operatorname{art} 28 /$

Espiner, S., and S. Becken. 2014. Tourist towns on the edge: conceptualising vulnerability and resilience in a protected tourism system. Journal of Sustainable Tourism 22(4):646-665. http://dx. doi.org/10.1080/09669582.2013.855222

Falk, M. 2010. A dynamic panel data analysis of snow depth and winter tourism. Tourism Management 31:912-924. http://dx.doi. org/10.1016/j.tourman.2009.11.010

Farrell, B. H., and L. Twining-Ward. 2004. Reconceptualizing tourism. Annals of Tourism Research 31(2):274-295. http://dx. doi.org/10.1016/j.annals.2003.12.002

Faulkner, B. 2001. Towards a framework for tourism disaster management. Tourism Management 22:135-147. http://dx.doi. org/10.1016/S0261-5177(00)00048-0

Flagestad, A., and C. A. Hope. 2001. Strategic success in winter sports destinations: a sustainable value creation perspective. Tourism Management 22(5):445-461. http://dx.doi.org/10.1016/ $\underline{\mathrm{s} 0261-5177(01) 00010-3}$

Folke, C. 2006. Resilience: the emergence of a perspective for social-ecological systems analyses. Global Environmental Change 16(3):253-267. http://dx.doi.org/10.1016/j.gloenvcha.2006.04.002

Folke, C., T. Hahn, P. Olsson, and J. Norberg. 2005. Adaptive governance of social-ecological systems. Annual Revue of Environment and Resources 30:441-473. http://dx.doi.org/10.1146/ annurev.energy.30.050504.144511

Formica, S., and T. H. Kothari. 2008. Strategic destination planning: analyzing the future of tourism. Journal of Travel Research 46:355-367. http://dx.doi.org/10.1177/0047287507312410

Girvan, M., and M. E. J. Newman. 2002. Community structure in social and biological networks. Proceedings of the National Academy of Sciences of the United States of America 99:7821-7826. http://dx.doi.org/10.1073/pnas.122653799

Guimerà, R., and L. A. N. Amaral. 2005a. Cartography of complex networks: modules and universal roles. Journal of Statistical Mechanics: Theory and Experiment 2005(02):P02001.

Guimerà, R., and L. A. N. Amaral. 2005b. Functional cartography of complex metabolic networks. Nature 433 (7028):895-900. http://dx.doi.org/10.1038/nature03288

Guimerà, R., L. Danon, A. Díaz-Guilera, F. Giralt, and A. Arenas. 2003. Self-similar community structure in a network of human interactions. Physical Review E 68(065103). http://dx.doi. org/10.1103/physreve.68.065103

Gunderson, L., and C. Holling, editors. 2002. Panarchy: understanding transformations in human and natural systems. Island Press, Washington, D.C., USA.

Hanssen, G. S., P. K. Mydske, and E. Dahle. 2013. Multi-level coordination of climate change adaptation: by national hierarchical steering or by regional network governance? Local Environment 18(8):869-887. http://dx.doi.org/10.1080/13549839.2012 .738657

Hassink, R. 2010. Regional resilience: a promising concept to explain differences in regional economic adaptability? Cambridge Journal of Regions, Economy and Society 3(1):45-58. http://dx.doi. org/10.1093/cjres/rsp033

Haugland, S. A., H. Ness, B.-O. Grønseth, and J. Aarstad. 2011. Development of tourism destinations: an integrated multilevel perspective. Annals of Tourism Research 38(1):268-290. http://dx. doi.org/10.1016/j.annals.2010.08.008

Hojman, D. A., and A. Szeidl. 2008. Core and periphery in networks. Journal of Economic Theory 139(1):295-309. http://dx. doi.org/10.1016/j.jet.2007.07.007

Holling, C. S. 1973. Resilience and stability of ecological systems. Annual Review of Ecology and Systematics 4:1-23. http://dx.doi. org/10.1146/annurev.es.04.110173.000245

Ingold, K., J. Balsiger, and C. Hirschi. 2010. Climate change in mountain regions: how local communities adapt to extreme events. Local Environment 15(7):651-661. http://dx.doi. org/10.1080/13549839.2010.498811

Kauffeld-Monz, M., and M. Fritsch. 2013. Who are the knowledge brokers in regional systems of innovation? A multiactor network analysis. Regional Studies 47(5):669-685. http://dx. doi.org/10.1080/00343401003713365

Kitchovitch, S., and P. Liò. 2011. Community structure in social networks: applications for epidemiological modelling. PLoS ONE 6(7):e22220. http://dx.doi.org/10.1371/journal.pone.0022220

Lambert, E., C. Hunter, G. J. Pierce, and C. D. MacLeod. 2010. Sustainable whale-watching tourism and climate change: towards a framework of resilience. Journal of Sustainable Tourism 18 (3):409-427. http://dx.doi.org/10.1080/09669581003655497

Lubell, M., G. Robins, and P. Wang. 2014. Network structure and institutional complexity in an ecology of water management games. Ecology and Society 19(4):23. http://dx.doi.org/10.5751/ es-06880-190423

Luthe, T., and R. Wyss. 2014. Assessing and planning resilience in tourism. Tourism Management 44:161-163. http://dx.doi. org/10.1016/j.tourman.2014.03.011

Luthe, T., and R. Wyss. 2015. Introducing adaptive waves as a concept to inform mental models of resilience. Sustainability Science 10(4):673-685. http://dx.doi.org/10.1007/s11625-015-0316-6

Luthe, T., R. Wyss, and M. Schuckert. 2012. Network governance and regional resilience to climate change: empirical evidence from mountain tourism communities in the Swiss Gotthard region. Regional Environmental Change 12(4):839-854. http://dx.doi. org/10.1007/s10113-012-0294-5 
Manring, S. L. 2007. Creating and managing interorganizational learning networks to achieve sustainable ecosystem management. Organization and Environment 20(3):325-346. http://dx.doi. org/10.1177/1086026607305738

Martin, R., and P. Sunley. 2006. Path dependence and regional economic evolution. Journal of Economic Geography 6 (4):395-437. http://dx.doi.org/10.1093/jeg/lb1012

Mayring, P. 2000. Qualitative Inhaltsanalyse. Grundlagen und Techniken Seventh edition. Deutscher Studien Verlag, Weinheim, Germany.

MeteoSwiss. 2013. Meteorological online data base IDAWEB from the Swiss federal office of climatology and meteorology. MeteoSwiss, Bern, Switzerland.

Michel, J. 2001. Erlebnis Berg: Qualitätsanforderungen an Luftseilbahnen und ihre Dienstleistungen. Berner Studien zu Freizeit und Tourismus, Bern, Switzerland.

Mizruchi, M. S. 1996. What do interlocks do? An analysis, critique, and assessment of research on interlocking directorates. Annual Review of Sociology 22:271-298. http://dx.doi. org/10.1146/annurev.soc.22.1.271

Mullins, N. C., L. L. Hargens, P. K. Hecht, and E. L. Kick. 1977. The group structure of cocitation clusters: a comparative study. American Sociological Review 42(4):552-562. http://dx.doi. org/10.2307/2094554

Murphy, P., M. P. Pritchard, and B. Smith. 2000. The destination product and its impact on traveler perceptions. Tourism Management 21:43-52. http://dx.doi.org/10.1016/S0261-5177(99) $\underline{00080-1}$

Nelson, D. R., W. N. Adger, and K. Brown. 2007. Adaptation to environmental change: contributions of a resilience framework. Annual Review of Environment and Resources 32:395-419. http:// dx.doi.org/10.1146/annurev.energy.32.051807.090348

Newman, M. E. J. 2004. Coauthorship networks and patterns of scientific collaboration. Proceedings of the National Academy of Sciences 101:5200-5205. http://dx.doi.org/10.1073/pnas.0307545100

Newman, M. E. J., and M. Girvan. 2004. Finding and evaluating community structure in networks. Physical Review E 69:026113. http://dx.doi.org/10.1103/physreve.69.026113

Nordin, S., and B. Svensson. 2007. Innovative destination governance: the Swedish ski resort of Åre. International Journal of Entrepreneurship and Innovation 8(1):53-66. http://dx.doi. org/10.5367/000000007780007416

O'Brien, K. 2012. Global environmental change II: from adaptation to deliberate transformation. Progress in Human Geography 36(5):667-676. http://dx.doi.org/10.1177/0309132511425767

Oh, H., M. Chung, and G. Labianca. 2004. Group social capital and group effectiveness: the role of informal socializing ties. Academy of Management Journal 47(6):860-875. http://dx.doi. org/10.2307/20159627

Olsson, P., C. Folke, V. Galaz, T. Hahn, and L. Schultz. 2007. Enhancing the fit through adaptive co-management: creating and maintaining bridging functions for matching scales in the Kristianstads Vattenrike Biosphere Reserve Sweden. Ecology and
Society 12(1):28. [online] URL: http://www.ecologyandsociety. org/vol12/iss1/art28/

Olsson, P., C. Folke, and T. Hahn. 2004. Social-ecological transformation for ecosystem management: the development of adaptive co-management of a wetland landscape in southern Sweden. Ecology and Society 9(4):2. [online] URL: http://www. ecologyandsociety.org/vo19/iss4/art2/

Onnela, J.-P., S. Arbesman, M. C. González, A. L. Barabási, and N. A. Christakis. 2011. Geographic constraints on social network groups. PLoS ONE 6(4):e16939. http://dx.doi.org/10.1371/ journal.pone.0016939

Organisation for Economic Co-operation and Development (OECD). 2007. Climate change in the European Alps. Volume 1. OECD, Paris, France. ISBN: 9789264031692.

Ostrom, E. 1990. Governing the commons: the evolution of institutions for collective action. Cambridge University Press, Cambridge, UK.

Oviero-Garcia, M. A., M. Castellanos-Verdugo, and D. MartinRuiz. 2008. Gaining residents' support for tourism and planning. International Journal of Tourism Research 10(2):95-109. http://dx. doi.org/10.1002/jtr.644

Pansiri, J. 2008. The effects of characteristics of partners on strategic alliance performance in the SME dominated travel sector. Tourism Management 29(1):101-115. http://dx.doi. org/10.1016/j.tourman.2007.03.023

Pechlaner, H., M. Volgger, and M. Herntrei. 2012. Destination management organizations as interface between destination governance and corporate governance. Anatolia 23(2):151-168. http://dx.doi.org/10.1080/13032917.2011.652137

Presenza, A., and M. Cipollina. 2010. Analysing tourism stakeholders networks. Tourism Review 65(4):17-30. http://dx.doi. org/10.1108/16605371011093845

Raich, F., and H. Pechlaner. 2006. Governance räumlicher Wettbewerbseinheiten: Ein Ansatz für die Tourismus-Destination. Deutscher Universitätsverlag, Wiesbaden, Germany.

Ritchie, B. W. 2004. Chaos, crises and disasters: a strategic approach to crisis management in the tourism industry. Tourism Management 25:669-683. http://dx.doi.org/10.1016/j.tourman.2003.09.004

Rodríguez-Diaz, M., and T. F. Espino-Rodríguez. 2008. A model of strategic evaluation of a tourism destination based on internal and relational capabilities. Journal of Travel Research 46:368-380. http://dx.doi.org/10.1177/0047287507308324

Rombach, M. P., M. A. Porter, J. H. Fowler, and P. J. Mucha. 2014. Core-periphery structure in networks. SIAM Journal on Applied Mathematics 74(1):167-190. http://dx.doi.org/10.1137/120881683

Ruhanen, L., N. Scott, B. Ritchie, and A. Tkaczynski. 2010. Governance: a review and synthesis of the literature. Tourism Review 65(4):4-16. http://dx.doi.org/10.1108/16605371011093836

Ruiz-Ballesteros, E. 2011. Social-ecological resilience and community-based tourism: an approach from Agua Blanca, Ecuador. Tourism Management 32(3):655-666. http://dx.doi. org/10.1016/j.tourman.2010.05.021 
Sainaghi, R. 2006. From contents to processes: versus a dynamic destination management model (DDMM). Tourism Management 27:1053-1063. http://dx.doi.org/10.1016/j.tourman.2005.09.010

Salau, K., M. L. Schoon, J. A. Baggio, and M. A. Janssen. 2012. Varying effects of connectivity and dispersal on interacting species dynamics. Ecological Modelling 242:81-91. http://dx.doi. org/10.1016/j.ecolmodel.2012.04.028

Sandström, A., and L. Carlsson. 2008. The performance of policy networks: the relation between network structure and network performance. Policy Studies Journal 36(4):497-524. http://dx.doi. org/10.1111/j.1541-0072.2008.00281.x

Saxena, G., and B. Ilbery. 2008. Integrated rural tourism a border case study. Annals of Tourism Research 35(1):233-254. http://dx. doi.org/10.1016/j.annals.2007.07.010

Schoon, M., J. A. Baggio, K. R. Salau, and M. Janssen. 2014. Insights for managers from modeling species interactions across multiple scales in an idealized landscape. Environmental Modelling and Software 54:53-59. http://dx.doi.org/10.1016/j. envsoft.2013.12.010

Scott, J. 2013. Social network analysis Third edition. SAGE, London, UK.

Scott, N., R. Baggio, and C. Cooper. 2008b. Network analysis and tourism: from theory to practice. Channel View Publications, Bristol, UK.

Scott, N., C. Cooper, and R. Baggio. 2008a. Destination networks: four Australian cases. Annals of Tourism Research 35(1):169-188. http://dx.doi.org/10.1016/j.annals.2007.07.004

Siegrist, D., C. Clivaz, M. Doctor, S. Gessner, L. Ketterer, T. Luthe, C. Matasci, M. Schuckert, and R. Wyss. 2013. Adaption des alpinen Tourismus an den Klimawandel: Ergebnisse der Alpine-Space Projekts ClimAlpTour in der Schweiz. Pages 145-158 in T. Bieger, P. Beritelli, and C. Laesser, editors. Nachhaltigkeit im alpinen Tourismus. Schweizer Jahrbuch für Tourismus. Erich Schmidt Verlag, Berlin, Germany.

Stocker, T. F., D. Qin, G.-K. Plattner, L. V. Alexander, S. K. Allen, N. L. Bindoff, F.-M. Bréon, J. A. Church, U. Cubasch, S. Emori, P. Forster, P. Friedlingstein, N. Gillett, J. M. Gregory, D. L. Hartmann, E. Jansen, B. Kirtman, R. Knutti, K. Krishna Kumar, P. Lemke, J. Marotzke, V. Masson-Delmotte, G. A. Meehl, I. I. Mokhov, S. Piao, V. Ramaswamy, D. Randall, M. Rhein, M. Rojas, C. Sabine, D. Shindell, L. D. Talley, D. G. Vaughan, and S.-P. Xie. 2013. Technical summary. Pages 33-115 in T. F. Stocker, D. Qin, G.-K. Plattner, M. Tignor, S. K. Allen, J. Boschung, A. Nauels, Y. Xia, V. Bex, and P. M. Midgley, editors. Climate change 2013: the physical science basis. Contribution of Working Group I to the Fifth Assessment Report of the Intergovernmental Panel on Climate Change Cambridge University Press, Cambridge, UK.

Strickland-Munro, J. K., H. E. Allison, and S. A. Moore. 2010. Using resilience concepts to investigate the impacts of protected area tourism on communities. Annals of Tourism Research 37 (2):499-519. http://dx.doi.org/10.1016/j.annals.2009.11.001

Svensson, B., S. Nordin, and A. Flagestad. 2005. A governance perspective on destination development-exploring partnerships, cluster and innovation systems. Tourism Review 60(2):32-37. http://dx.doi.org/10.1108/eb058455

Ter Wal, A. L. J., and R. A. Boschma. 2009. Applying social network analysis in economic geography: framing some key analytic issues. Annals of Regional Science 43(3):739-756. http:// dx.doi.org/10.1007/s00168-008-0258-3

Tinsley, R., and P. Lynch. 2001. Small tourism business networks and destination development. International Journal of Hospitality Management 20(4):367-378. http://dx.doi.org/10.1016/s0278-4319 (01)00024-X

Uhlmann, B., S. Goyette, and M. Beniston. 2009. Sensitivity analysis of snow patterns in Swiss ski resorts to shifts in temperature, precipitation and humidity under conditions of climate change. International Journal of Climatology 29:1048-1055. http://dx.doi.org/10.1002/joc.1786

Valente, T. W. 1995. Network models of the diffusion of innovations. Hampton, Cresskill, New Jersey, USA.

Walker, B., C. S. Holling, S. R. Carpenter, and A. Kinzig. 2004. Resilience, adaptability and transformability in social-ecological systems. Ecology and Society 9(2):5. [online] URL: http://www. ecologyandsociety.org/vo19/iss2/art5/

Wang, Y., and Z. Xiang. 2007. Toward a theoretical framework of collaborative destination marketing. Journal of Travel Research 46:75-85. http://dx.doi.org/10.1177/0047287507302384

Wasserman, S., and K. Faust. 1994. Social network analysis: methods and applications. Eighth edition. Cambridge University Press, Cambridge, UK. http://dx.doi.org/10.1017/cbo9780511815478

Wyss, R., B. Abegg, and T. Luthe. 2014. Perceptions of climate change in a mountain tourism context. Tourism Management Perspectives 44:161-163.

Wyss, R., T. Luthe, and B. Abegg. 2015. Building resilience to climate change - the role of cooperation in alpine tourism networks. Local Environment. 20(8):908-922. http://dx.doi. org/10.1080/13549839.2013.879289

Young, O. R. 2002. The institutional dimensions of environmental change: fit, interplay, and scale. MIT Press, Cambridge, Massachusetts, USA. ISBN 0-262-24043-2.

Zehrer, A., and F. Raich. 2010. Applying a lifecycle perspective to explain tourism network development. Service Industries Journal 30(10):1683-1705. http://dx.doi.org/10.1080/02642060903580698

Zeppel, H. 2012. Climate change and tourism in the Great Barrier Reef Marine Park. Current Issues in Tourism 15(3):287-292. http:// dx.doi.org/10.1080/13683500.2011.556247 